\title{
Ganoderma lucidum polysaccharides in human monocytic leukemia cells: from gene expression to network construction Kun-Chieh Cheng ${ }^{\dagger 1,2}$, Hsuan-Cheng Huang ${ }^{\dagger 3}$, Jenn-Han Chen ${ }^{4}$, Jia- Wei Hsu ${ }^{5}$, Hsu-Chieh Cheng ${ }^{1}$, Chern-Han Ou ${ }^{1,6}$, Wen-Bin Yang7, Shui- Tein Chen 7,8, Chi-Huey Wong7,8,9 and Hsueh-Fen Juan*1,5,10,11
}

Address: ${ }^{1}$ Department of Life Science, National Taiwan University, Taipei 106, Taiwan, ${ }^{2}$ Institute of Biotechnology, National Taipei University of Technology, Taipei 106, Taiwan, ${ }^{3}$ Institute of Biomedical Informatics, National Yang-Ming University, Taipei 112, Taiwan, ${ }^{4}$ School of Dentistry, National Defense Medical center, National Defense University, Taipei 114, Taiwan, ${ }^{5}$ Institute of Molecular and Cellular Biology, National Taiwan University, Taipei 106, Taiwan, ${ }^{6}$ Department of Electronic Engineering, National Taiwan University, Taipei, Taiwan, ${ }^{7}$ Institute of Biological Chemistry and the Genomics Research Center, Academia Sinica, Taipei 115, Taiwan, ${ }^{8}$ Institute of Biochemical Sciences, National Taiwan University, Taipei 106, Taiwan, ${ }^{9}$ Department of Chemistry and The Skaggs Institute for Chemical Biology, The Scripps Research Institute, La Jolla, CA 92037, USA, ${ }^{10}$ Institute of Biomedical Electronics and Bioinformatics, National Taiwan University, Taipei 106, Taiwan and ${ }^{11}$ Center for Systems Biology and Bioinformatics, National Taiwan University, Taipei 106, Taiwan

Email: Kun-Chieh Cheng - jerekcheng@gmail.com; Hsuan-Cheng Huang - hsuancheng@ym.edu.tw; Jenn-Han Chen - jhc.ndmc@msa.hinet.net; Jia-Wei Hsu - monkey810676@hotmail.com; Hsu-Chieh Cheng - voicejimmy@gmail.com; Chern-Han Ou - b91901120@ntu.edu.tw; WenBin Yang - wbyang@gate.sinica.edu.tw; Shui-Tein Chen - bcchen@gate.sinica.edu.tw; Chi-Huey Wong - chwong@gate.sinica.edu.tw; HsuehFen Juan* - yukijuan@ntu.edu.tw

* Corresponding author †Equal contributors

Published: 9 November 2007

BMC Genomics 2007, 8:4II doi:|0.||86/|47|-2164-8-4|I
Received: 26 July 2007

Accepted: 9 November 2007

This article is available from: http://www.biomedcentral.com/|47|-2/64/8/4|I

(C) 2007 Cheng et al; licensee BioMed Central Ltd.

This is an Open Access article distributed under the terms of the Creative Commons Attribution License (http://creativecommons.org/licenses/by/2.0), which permits unrestricted use, distribution, and reproduction in any medium, provided the original work is properly cited.

\begin{abstract}
Background: Ganoderma lucidum has been widely used as a herbal medicine for promoting health and longevity in China and other Asian countries. Polysaccharide extracts from Ganoderma lucidum have been reported to exhibit immuno-modulating and anti-tumor activities. In previous studies, $\mathrm{F} 3$, the active component of the polysaccharide extract, was found to activate various cytokines such as IL-I, IL-6, IL-I2, and TNF- $\alpha$. This gave rise to our investigation on how F3 stimulates immuno-modulating or anti-tumor effects in human leukemia THP-I cells.

Results: Here, we integrated time-course DNA microarray analysis, quantitative PCR assays, and bioinformatics methods to study the F3-induced effects in THP-I cells. Significantly disturbed pathways induced by $\mathrm{F} 3$ were identified with statistical analysis on microarray data. The apoptosis induction through the DR3 and DR4/5 death receptors was found to be one of the most significant pathways and play a key role in THP-I cells after F3 treatment. Based on time-course gene expression measurements of the identified pathway, we reconstructed a plausible regulatory network of the involved genes using reverse-engineering computational approach.
\end{abstract}

Conclusion: Our results showed that $\mathrm{F} 3$ may induce death receptor ligands to initiate signaling via receptor oligomerization, recruitment of specialized adaptor proteins and activation of caspase cascades. 


\section{Background}

Ganoderma lucidum (G. lucidum, Reishi or Ling-Zhi) has been used in traditional Chinese medicine as an antitumor medication or as an immuno-modulator. Many reports showed Reishi extracts to possess anti-proliferative effects on many cancers, such as acute myelogenous leukemia [1], lung cancer [2], breast cancer [3], colorectal cancer [4], bladder cancer [5] and prostate cancer [6,7]. A fucose-containing polysaccharide fraction (F3), isolated from the water-soluble Reishi extract, is able to stimulate spleen cell proliferation and cytokine expression [8-11]. Understanding how the molecular mechanism is responsible for the effects of F3 on cancer cells remains to be elucidated and will require whole-system approaches, since isolated single molecular studies have not, so far, been able to unlock cancer-system complexity. Microarray analysis is the first step in understanding integrated cell functions and cell-specific gene-expression profiles. The response of cells to external stimuli can be followed over a period of time by measuring the differences in global gene expression. Global transcription analysis provides a new approach to the description of complex biological phenomena [12-14]; it is also of great use in the field of cancer biology [15-19].

Networks of interacting proteins can provide researchers rudimentary understanding in cellular mechanisms; therefore, it is possible to understand the cellular functions of Reishi polysaccharide (F3) through their linkages to characterized receptors. In broader terms, networks of gene linkages offer a new view on the meaning of F3 function, and in time should provide us with a more in-depth understanding of the function of cells [20]. Traditionally, protein-polysaccharide interactions have been studied individually by genetic, biochemical or biophysical techniques. However, the speed of which new proteins are being discovered or predicted has created a need for highthroughput interaction-detection methods. Consequently, in the last two years, more efficient methods have been introduced to tackle the problem globally, and in turn provide researchers with vast amount of interaction data [21]. In silico (computational) interaction predictions derived from gene context analysis (gene fusion [22,23], gene neighborhood [24,25] and gene co-occurrences or phylogenetic profiles [26,27]) and chip-based analysis have been reported [28]. However, little knowledge has been obtained with regard to protein-polysaccharide interactions. Identifying protein-F3 interactions and constructing anti-cancer pathways are quite important in revealing the molecular mechanisms involved in anti-cancer activities.

Tumor necrosis factor-related apoptosis inducing ligand (TRAIL, also called Apo2L or TNFSF10) is capable of inducing apoptosis in cancer cells but not in normal cells
[29]. It is possible that certain connection to the Apo2L signaling pathway contributes to anti-tumor activities. Apo2L seems to be a potential candidate for anti-cancer drug [30]. The four cellular receptors binding to Apo2L are death receptor 4 (DR4, also called TRAIL-R1), death receptor 5 (DR5, also called Apo2, TRAIL-R2, TRICK 2, TNFRSF10B or Killer), decoy receptor 1 (DcR1 or TRAILR3) and decoy receptor 2 (DcR2 or TRAIL-R4) [31-33]. Death receptors belonging to the tumor necrosis factor (TNF) receptor gene family are defined by cysteine-rich extracellular domains [34,35]. Signals induced by these ligand-receptor interactions serve the function of activating or inducing cell death by apoptosis.

In this study, we intend to find out whether F3 has similar interactions with death receptors that stimulate apoptosis pathways in leukemia cells. To study how leukemia cells are conditioned by F3, we carried out a dynamic analysis of gene expression in THP-1 cells, a monocytic leukemia cell line, with F3 treatment at different time points. In this article, we used oligonucleotide microarray and real-time quantitative PCR to detect dynamic gene expression profiles; and through bioinformatics approach, we also constructed a gene network. Finally, we illustrated possible molecular regulations of Ganoderma lucidum polysaccharides in human monocytic leukemia cells.

\section{Results and discussion}

G. lucidum has been used for long time to modulate immune system and to prevent or treat various human diseases [36]. The biologically active compounds originally isolated and purified from G. lucidum were identified as polysaccharides, and the main fraction was designated as F3 [11]. Although the anti-tumor activity of G. lucidum associated with polysaccharides was wellestablished in vitro and in vivo, detailed mechanisms of how they work still await to be elucidated [36]. Understanding how polysaccharides (F3) stimulate anti-tumor effects in THP-1 cells is quite important. From gene expression to the construction of gene network, our results contribute to the understanding of the molecular mechanisms of F3 exertion on THP-1 cells. Two molecular mechanisms of F3-induced immunomodulation activities, including TLR4 and TLR2 signal pathways, have been studied $[9,10]$. In this study, we explored the gene expression and gene network induced by F3 in leukemia THP-1 cells, and aimed to reveal pathways critical in F3-induced anti-cancer activity.

\section{The induction of TNF- $\alpha$ in F3-treated human monocytic cells THP-I}

Upon the binding of TNF- $\alpha$ to TNFR1, monocytic cells are triggered to undergo apoptosis. This critical regulatory process is accomplished by activating the caspase cascade that results in the degradation of various important cellu- 
lar proteins. Previous reports showed that lipopolysaccharide (LPS) could markedly stimulate the cytokine expression, especially TNF- $\alpha$ [37]. Compared with the TNF- $\alpha$ expression in LPS-induced THP-1 cells, we could estimate the optimal effect concentration of F3. We treated THP- 1 cells with different F3 concentrations (1, $10,50,100,200 \mu \mathrm{g} / \mathrm{mL})$ and LPS ( $1 \mu \mathrm{g} / \mathrm{mL})$ for 24 hours, and measured their TNF- $\alpha$ expressions. Figure 1 demonstrates that F3 was dose dependent in the activation of TNF- $\alpha$ expression. TNF- $\alpha$ expression stimulated by F3 at $100 \mu \mathrm{g} / \mathrm{mL}$ and $200 \mu \mathrm{g} / \mathrm{mL}$ was similar to that of LPS at 1 $\mu \mathrm{g} / \mathrm{mL}$. From these TNF- $\alpha$ expression data, we calculated the $\mathrm{EC}_{50}(50 \%$ effect concentration) of F3-induced effectiveness to be around $10 \mu \mathrm{g} / \mathrm{mL}$. If $70 \%$ of TNF- $\alpha$ is expressed in F3-induced cells compared to LPS-induced cells, then $30 \mu \mathrm{g} / \mathrm{mL}$ of $\mathrm{F} 3$ is required to achieve the same effectiveness. For further experiments, we used $30 \mu \mathrm{g} / \mathrm{mL}$ of F3 to treat THP-1 cells.

\section{Apoptotic effect of F3 on THP-I cells}

After THP-1 cells were treated with F3 $(30 \mu \mathrm{g} / \mathrm{mL})$ for 48 hours, we observed the change of cell morphology under phase-contrast microscope. Differences in cell morphology can be detected between un-treated and F3-treated THP-1 cells. In Figure 2, representative photos of DAPI-

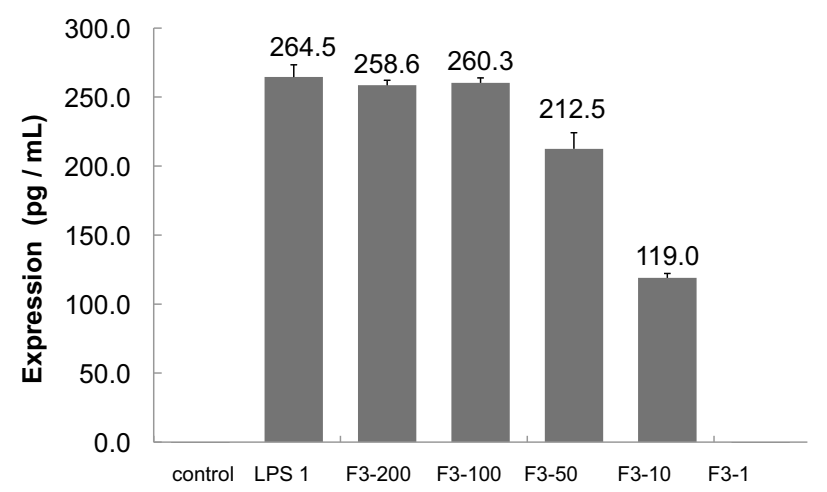

\section{Figure I}

The expression of TNF- $\alpha$ in F3- or LPS-induced THPI cells. $10^{5}$ cells $/ \mathrm{mL}$ concentrations of THP-I cells were seeded in 96-well microplates and incubated overnight. Then the cells $\left(1.25 \times 10^{4}\right)$ were treated with $\mathrm{F} 3$ at dosages indicated as I $\mu \mathrm{g} / \mathrm{mL}, 10 \mu \mathrm{g} / \mathrm{mL}, 50 \mu \mathrm{g} / \mathrm{mL}, 100 \mu \mathrm{g} / \mathrm{mL}, 200 \mu \mathrm{g} /$ $\mathrm{mL}$, and with LPS at the dose of I $\mu \mathrm{g} / \mathrm{mL}$, respectively. The same volume of medium was used as control After 24 hours, the supernatants were collected and in vitro TNF- $\alpha$ activity was determined using Human TNF- $\alpha$ Immunoassay Kit (Quantikine ${ }^{\circledR}, \mathrm{RD}$ systems). TNF- $\alpha$ expression induced by F3 ( $100 \mu \mathrm{g} / \mathrm{mL}$ and $200 \mu \mathrm{g} / \mathrm{mL}$ ) is similar to that of LPS (I $\mu \mathrm{g} /$ $\mathrm{mL})$. From this TNF- $\alpha$ expression data, we calculated the $\mathrm{EC}_{50}(50 \%$ effect concentration) of $\mathrm{F} 3$-induced to be around $10 \mu \mathrm{g} / \mathrm{mL}$. The error bars indicate SD from triplicate independent experiments. staining results are shown. Cell shrinkage, one of cell death characteristics, happened in THP-1 cells after 48 hours treatment with F3 (Figure 2A and 2B). During cell apoptosis, an early event is the nuclear chromatin condensation, leading to the degradation of genomic DNA. DAPI nuclear staining was performed to check the apoptotic changes shown by cell morphology (Figure 2C and 2D). The percentage of chromatin condensed cells in F3-treated culture saw a significant increase (Figure 2E). Shrunken nucleus and apoptotic bodies in DAPI staining were features in determining whether cells had undergone apoptosis. These results indicated that incubation of THP-1 cells with F3 for 48 hours would lead to cell aggregations and apoptosis.

Recent studies showed G. lucidum to induce apoptosis in many cancer cells such as lung cancer cells [38], leukemia cells $[39,40]$, murine skin carcinoma cells [41], colonic carcinoma cells [42], prostate cancer cells [6], and breast

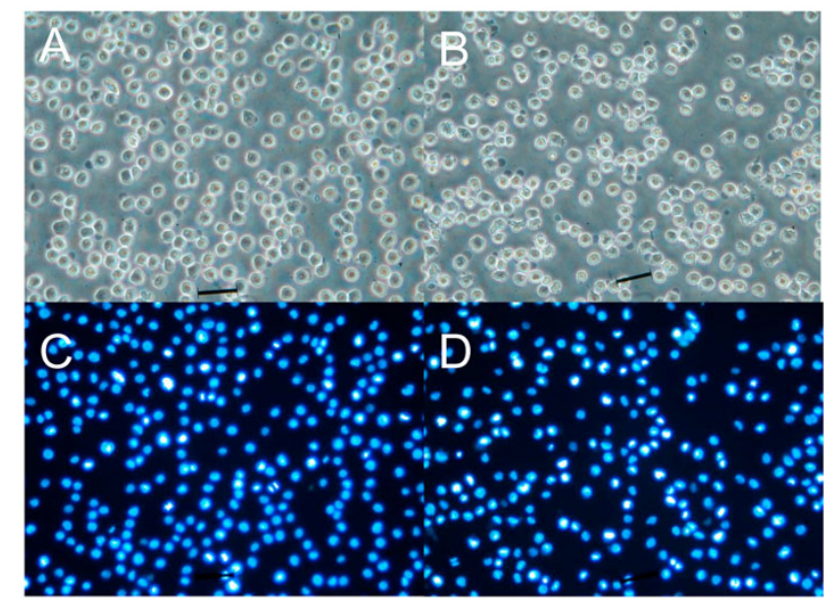

$\mathrm{E}$

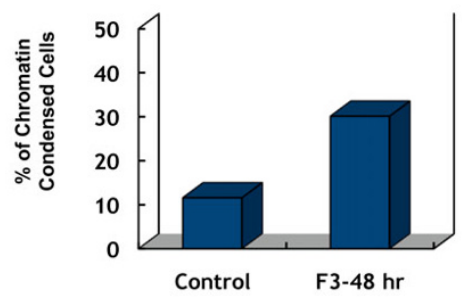

Figure 2

Characterization of F3 induced cell death in human THP-I cells. Phase-contrast microscopy was used to detect the morphology of the control (A) and F3-treated THP-I cells (B). Cell shrinkage, shape irregularity, and cellular detachment were observed in F3-treated cells, but not in the control. The control (C) and F3-treated THP-I cells (D) were stained with 4, 6-diamidino- 2-phenylindole (DAPI). (E) The percentage of chromatin condensed cells. There was apparent difference in cell morphology between the untreated and F3-treated THP-I cells. 
cancer cells [43]. In our study, we shared the same results with other reports, but more specifically in that F3 extracted from G. lucidum could in fact induce apoptosis of leukemia cells THP-1. In our effort to better understand the mechanism of this apoptotic effect, we used microarray, a high-throughput technique, to measure the dynamic gene expression in F3-treated THP-1 cells.

\section{Microarray analysis of overall gene expression in F3- induced THP-I cells}

In order to identify patterns of gene expression associated with apoptotic effect in THP-1 cells induced by F3, we performed a transcriptomic analysis on the THP-1 control and F3-treated or LPS-treated THP-1 cells by oligonucleotide microarray. In Figure 3, we observed clear separation of control ( 0 and 6 hours) and F3-treated ( 6 and 24 hours) samples after performing principle component analysis on the gene expression profiles measured by microarray experiments. Figure 4 shows the flow chart for our microarray data analysis. In Figure 5, the intensities of gene expression of one experiment were plotted on the $x$ axis and the intensities of the other experiment on the $y$ axis. A single dot represents one gene as shown in the scatter plots. The upper three scatter plots showed no difference between the control experiments for 0 hour and 6 hours. These results showed the consistency of our duplicate microarray experiments.

Genes with 2-fold change in gene expressions between THP-1 control and F3- or LPS-treated THP-1 cells were selected for mapping significantly disturbed biological pathways. The pathway of apoptosis induction through the DR3 and DR4/5 death receptors was observed to be significant $(\mathrm{p}<0.05)$ in F3-treated THP-1 cells.

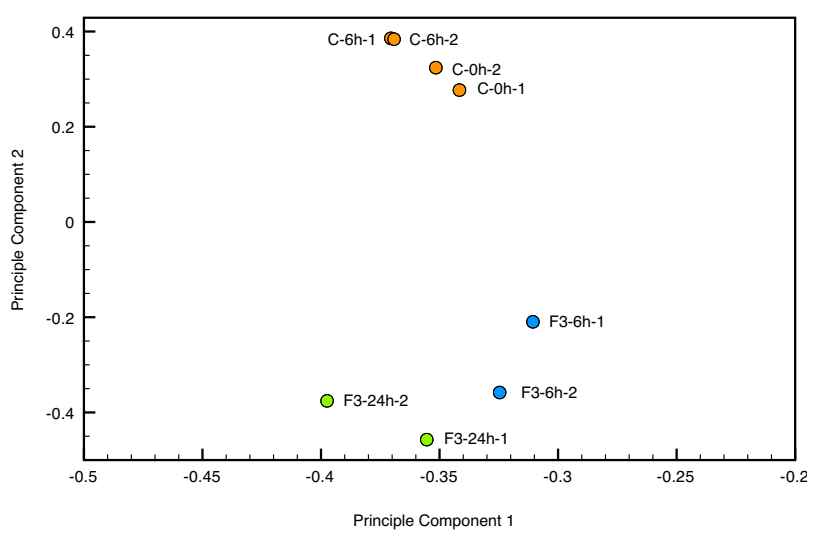

\section{Figure 3}

The scatter plot depicting the separation of control $(0$ and 6 hours) and F3-treated ( 6 and 24 hours) samples based on the first two principle components derived from the gene expression profiles measured by microarray experiments.

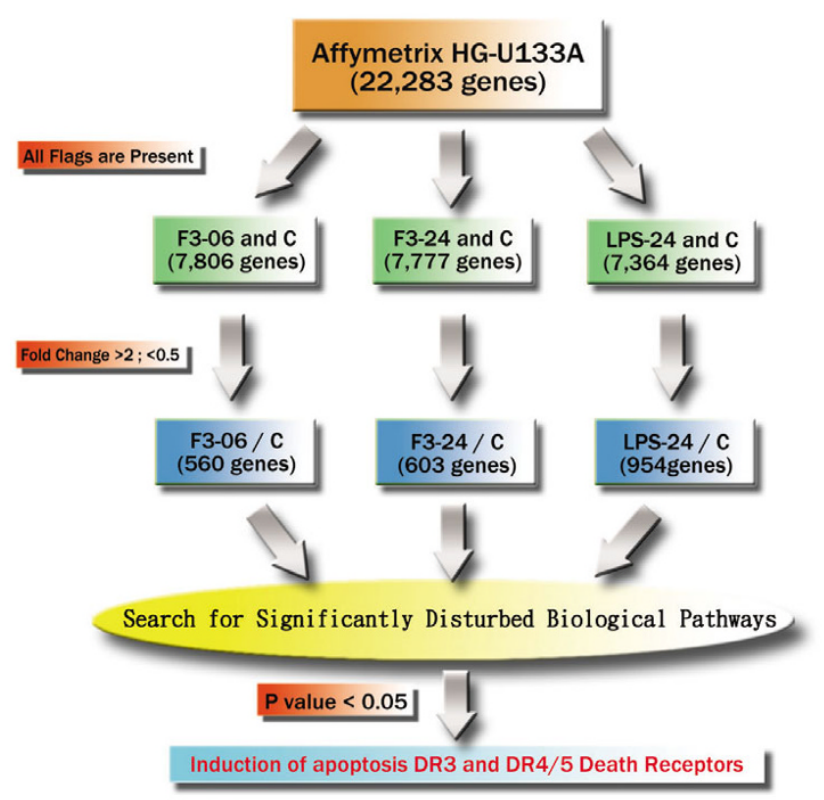

\section{Figure 4}

The flow chart for the microarray data analysis. We used Affymetrix HG-UI33A chip GeneChip oligonucleotide microarray. Initial data analysis was performed using Affymetrix Microarray Suite v5.0 software, setting the scaling of all probe sets to a constant value of 500 for each GeneChip. Additional data analysis was performed using GeneSpring v 5.I (Silicon Genetics Inc., Redwood City, California). Genes with a 2 -fold change in differential expression between THPI control and F3- or LPS-treated THP-I cells were selected for mapping significantly disturbed biological pathways. The pathway of apoptosis induction through the DR3 and DR4/5 death receptors was shown to be very significant in F3treated THP-I cells. F3-6 h and F3-24 h indicate the F3treated THPI cells after 6 hours and 24 hours, respectively. LPS-24 $\mathrm{h}$ indicates the LPS-treated THPI cells after 24 hours. C- $0 \mathrm{~h}$ and C- $6 \mathrm{~h}$ indicate the control THPI cells (without any treatment) in 0 hour and 6 hours, respectively.

\section{Significant biological pathways related to F3-induced THP-I cells}

The differentially expressed genes were annotated to specific biological pathways. For each UniGene ID, we retrieved its biological pathways from either BioCarta [44] or KEGG [45] through the existing NCI CGAP gene information database [46]. Biological pathways were mapped and sorted on the order of matching significance using ArrayXPath [47]. Table 1 shows the significant biological pathways induced by F3 in THP-1 cells. In this study, four pathways, including TNFR2 signaling pathway, induction of apoptosis through DR3 and DR4/5 death receptors, NF$\kappa \mathrm{B}$ signaling pathway, and toll-like receptor pathway may be involved in F3-induced cell death. The pathway of apoptosis induction through DR3 and DR4/5 death receptors was found to be the most significant pathway in F3- 

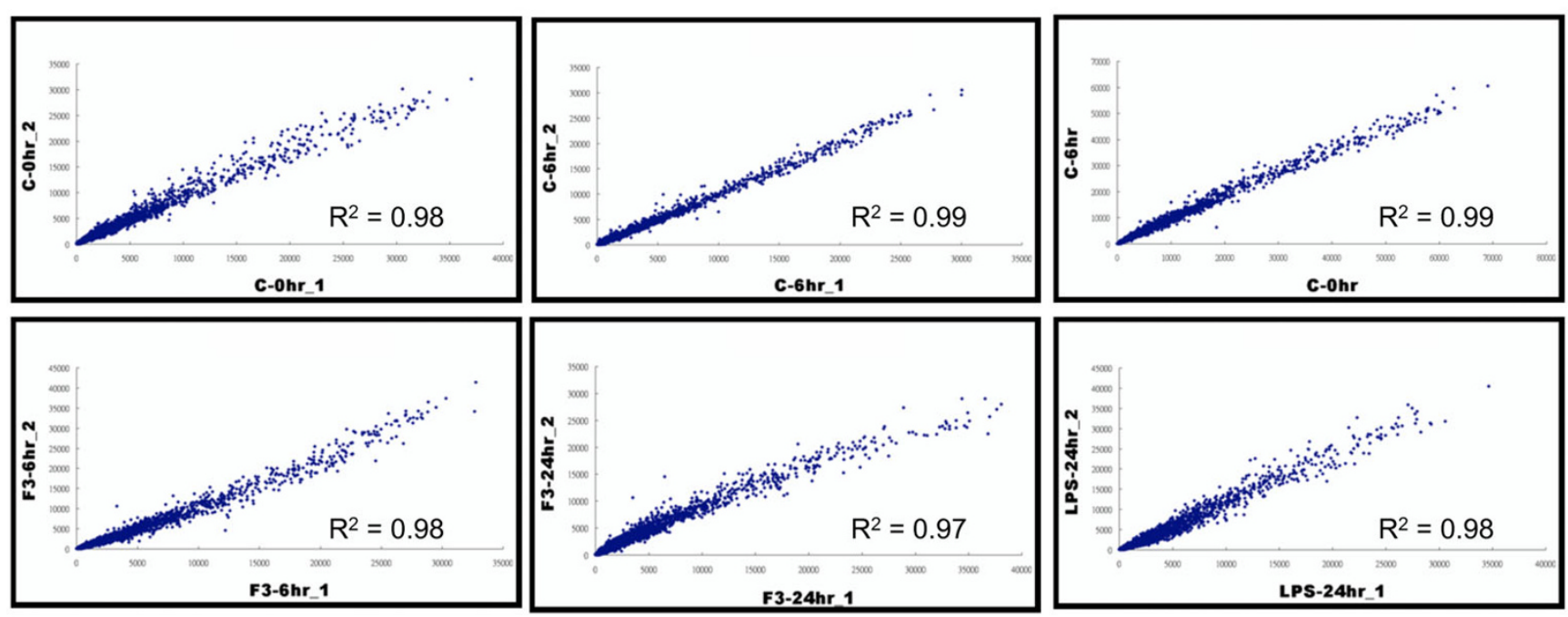

\section{Figure 5}

Scatter plot of the gene expressions in the repeated microarray experiments. The filtered probe intensities of gene expression of one experiment were plotted on the $x$ axis while the intensities of the other experiment were plotted on the $y$ axis. Each gene was represented by a single dot in the scatter plot. The upper three scatter plots showed no difference between control experiments for 0 hour and 6 hours. These results showed the consistency in duplicate microarray experiments.

treated THP-1 cells for 6 hours. Detailed gene expression profiles of these four pathways after F3 or LPS treatments are shown in Table 2. Our findings implicated that multiple mechanisms may be involved in the anti-tumor effects of F3 extracted from G. lucidum.

In the pathway of apoptosis induction through DR3 and DR4/5 death receptors, 9 genes were found to be up-regulated and 2 to be down-regulated among the 27 genes in F3-treated THP-1 cells after F3 treatment for 6 hours. The 9 up-regulated genes include tumor necrosis factor (ligand) superfamily, member 10 (TNFSF10 or TRAIL), tumor necrosis factor receptor superfamily, member 10b (TNFRSF10B or DR5), caspase 10, apoptosis-related cysteine peptidase (CASP10), BH3 interacting domain death agonist (BID), CASP8 and FADD-like apoptosis regulator (CFLAR), TNFRSF1A-associated via death domain (TRADD), nuclear factor of kappa light polypeptide gene enhancer in B-cells inhibitor, alpha (NFKBIA), nuclear factor of kappa light polypeptide gene enhancer in B-cells 1 (NFKB1), and caspase 7, apoptosis-related cysteine peptidase (CASP7); all of these genes are involved in cell death. Two down-regulated genes were DNA fragmentation factor, $40 \mathrm{kDa}$, beta polypeptide (caspase-activated DNase, DFFB) and caspase 6, apoptosis-related cysteine peptidase (CASP6). CASP6 cleavage by caspase-3 (CASP3), caspase-8 (CASP8) or -10 (CASP10) generates the two active subunits. In the microarray gene expression results, CASP3 and CASP8 showed no significant difference after F3 treatment. However, in our Q-PCR gene expression results, CASP8 showed a significant up-regulated expression. CASP3 and CASP7 were cleaved into their active forms after F3 treatment as shown in Figure 6. In summary, F3 may bind to death receptor $4 / 5$, and activate downstream apoptosis-related cysteine peptidase such as CASP8, CASP3 and CASP7, leading to the apoptosis of THP-1 cells.

The NF- $\kappa \mathrm{B}$ signaling pathway includes 21 genes among which 6 genes were up-regulated after treatment with F3. These six genes were TRADD, myeloid differentiation primary response gene (88) (MYD88), interleukin 1, alpha (IL1A), interleukin 1, beta (IL1B), NFKBIA and NFKB1. All of these genes are involved and are crucial in cell death. IL1B at low concentration induced strong apoptotic responses as revealed by caspase- 8 activation and DNA fragmentation [48]. MYD88 is an adapter protein involved in Toll-like receptor and IL-1 receptor signaling pathways in the innate immune response and acts via interleukin-1 receptor-associated kinase (IRAK1) and TNF receptor-associated factor 6 (TRAF6), leading to NF- $\kappa$ B activation, cytokine secretion and inflammatory responses. MYD88 can also induce IL-8 transcription and may be involved in myeloid differentiation. TRADD was observed to be overexpressed over 25 -fold after F3 treatment for 3 hours. TRADD is an adapter protein in the tumor necrosis factor receptor superfamily, in which member 1A (TNFRSF1A/TNFR1) specifically associates with the cytoplasmic domain of activated TNFRSF1A/ TNFR1, mediating its interaction with Fas (TNFRSF6)- 
Table I: Significantly Disturbed Pathways of F3/LPS-treated THP-I Cells

\begin{tabular}{|c|c|c|c|}
\hline Pathway & Identified $^{\mathrm{a}}$ & p-value & q-value \\
\hline \multicolumn{4}{|l|}{ F3 treatment after $6 \mathrm{hr}$} \\
\hline Induction of apoptosis through DR3 and DR4/5 Death Receptors & $9 / 32(37)$ & 0 & 0.0044 \\
\hline Erythropoietin mediated neuroprotection through NF-kB & $5 / 11(17)$ & 0.0002 & 0.0110 \\
\hline \multicolumn{4}{|l|}{ F3 treatment after $24 \mathrm{hr}$} \\
\hline Inhibition of Matrix Metalloproteinases & $3 / 9(15)$ & 0.0146 & 0.0265 \\
\hline Induction of apoptosis through DR3 and DR4/5 Death Receptors & $6 / 32(37)$ & 0.0116 & 0.0265 \\
\hline IFN alpha signaling pathway & $3 / 9(25)$ & 0.0146 & 0.0265 \\
\hline Chaperones modulate interferon Signaling Pathway & $4 / 16(34)$ & 0.0140 & 0.0265 \\
\hline NF-kB Signaling Pathway & $5 / 23(49)$ & 0.0112 & 0.0265 \\
\hline TNFR2 Signaling Pathway & $5 / 18(32)$ & 0.0036 & 0.0265 \\
\hline CD40L Signaling Pathway & $4 / 15(27)$ & 0.0110 & 0.0265 \\
\hline Bone Remodelling & $4 / 14$ (19) & 0.0085 & 0.0265 \\
\hline B Lymphocyte Cell Surface Molecules & $3 / 9(10)$ & 0.0146 & 0.0265 \\
\hline Double Stranded RNA Induced Gene Expression & $3 / 10(14)$ & 0.0199 & 0.0321 \\
\hline Antisense Pathway & $2 / 4(13)$ & 0.0208 & 0.0321 \\
\hline The information-processing pathway at the IFN-beta enhancer & $4 / 15(27)$ & 0.0110 & 0.0440 \\
\hline \multicolumn{4}{|l|}{ LPS treatment after $24 \mathrm{hr}$} \\
\hline B Lymphocyte Cell Surface Molecules & $5 / 9(10)$ & 0.0006 & 0.0122 \\
\hline Erythropoietin mediated neuroprotection through NF-kB & $5 / 11(17)$ & 0.0019 & 0.0191 \\
\hline Induction of apoptosis through DR3 and DR4/5 Death Receptors & $8 / 32(37)$ & 0.0071 & 0.0356 \\
\hline IFN alpha signaling pathway & $4 / 9(25)$ & 0.0063 & 0.0356 \\
\hline NFkB activation by Nontypeable Hemophilus influenzae & $6 / 24(43)$ & 0.0194 & 0.0481 \\
\hline Toll-Like Receptor Pathway & $7 / 34(45)$ & 0.0331 & 0.0481 \\
\hline TNFR2 Signaling Pathway & $5 / 18(32)$ & 0.0207 & 0.0481 \\
\hline CD40L Signaling Pathway & $4 / 15(27)$ & 0.0438 & 0.0481 \\
\hline IL-10 Anti-inflammatory Signaling Pathway & $4 / 13(17)$ & 0.0266 & 0.0481 \\
\hline HIV-I Nef: negative effector of Fas and TNF & 10/57 (77) & 0.0338 & 0.0481 \\
\hline Neuropeptides VIP and PACAP inhibit the apoptosis of activated T cells & $6 / 26(43)$ & 0.0283 & 0.0481 \\
\hline HIV-I defeats host-mediated resistance by CEMI5 & $2 / 3(5)$ & 0.0243 & 0.0481 \\
\hline Bone Remodelling & $4 / 14(19)$ & 0.0346 & 0.0481 \\
\hline Neutrophil and Its Surface Molecules & $3 / 8(12)$ & 0.0313 & 0.0481 \\
\hline Adhesion Molecules on Lymphocyte & $3 / 9(10)$ & 0.0438 & 0.0481 \\
\hline GATA3 participate in activating the Th2 cytokine genes expression & $5 / 16(25)$ & 0.0123 & 0.0481 \\
\hline Oxidative reactions of the pentose phosphate pathway & $2 / 4(4)$ & 0.0457 & 0.0481 \\
\hline NF-kB Signaling Pathway & $5 / 23(49)$ & 0.0558 & 0.0487 \\
\hline Chaperones modulate interferon Signaling Pathway & $4 / 16(34)$ & 0.0543 & 0.0487 \\
\hline Double Stranded RNA Induced Gene Expression & $3 / 10(14)$ & 0.0584 & 0.0487 \\
\hline Mechanism of Gene Regulation by Peroxisome Proliferators via PPARa(alpha) & $9 / 54(64)$ & 0.0574 & 0.0487 \\
\hline FAS signaling pathway (CD95) & $6 / 30(34)$ & 0.0536 & 0.0487 \\
\hline The information-processing pathway at the IFN-beta enhancer & $4 / 15(27)$ & 0.0438 & 0.0487 \\
\hline
\end{tabular}

a The ratio between matching genes and total genes in this pathway

associated via the death domain (FADD) [31]. Overexpression of TRADD leads to two major TNF-induced responses, apoptosis and the activation of NF- $\kappa \mathrm{B}$. NF- $\kappa \mathrm{B}$ is a transcription factor regulating the expressions of a large number of genes critical in apoptosis regulation. NF$\kappa \mathrm{B}$ is strongly activated shortly after TNF engagement with TNFR1, generating a pro-survival signal that must be overcome in many cell types for TNF to induce apoptosis [31]. Many reports also showed that Apo2L/TRAIL could activate NF- $\kappa B[29,49]$. In our results, activation of the NF- $\kappa B$ signaling pathway caused further THP-1 cell death after F3 treatment.
The TNFR2 signaling pathway includes 17 genes among which 7 genes were differentially expressed in F3- or LPStreated THP-1 cells. All of these seven genes were up-regulated after treatments with F3 or LPS, as shown in Table 2. TNF binds to two different receptors, TNF receptor 1 (TNFR1) and TNFR2 (TNFRSF1B). TNFR2 is produced by activating lymphocytes and can be cytotoxic to many types of tumors and cells. TNFR2 expression is to mediate the anti-tumor effect of TNF, and NO is necessary for this process, possibly by inhibiting angiogenesis in the tumor [50]. Like TNFR2, TNF receptor-associated factor 1 (TRAF1) was also up-regulated in F3- or LPS-treated THP- 
Table 2: Differentially expressed genes of F3- or LPS-induced THP-I cells using oligonucleotide microarray

\begin{tabular}{|c|c|c|c|c|c|}
\hline \multirow[t]{2}{*}{ Pathway } & \multirow[t]{2}{*}{ Gene } & \multirow[t]{2}{*}{ Gene Description } & \multicolumn{3}{|c|}{ Fold Change } \\
\hline & & & $\mathrm{F} 3-6 \mathrm{hr} / \mathrm{C}$ & $\mathrm{F} 3-24 \mathrm{hr} / \mathrm{C}$ & LPS-24 hr/C \\
\hline \multirow{27}{*}{$\begin{array}{l}\text { Induction of apoptosis } \\
\text { through DR3 and DR } 4 / 5 \\
\text { Death Receptors }\end{array}$} & TNFSFI0* & tumor necrosis factor (ligand) superfamily, member 10 & 9.9 & 10.1 & 18.4 \\
\hline & TNFRSFIOB* & tumor necrosis factor receptor superfamily, member $10 \mathrm{~b}$ & 2.1 & 2.4 & 2.8 \\
\hline & CASP8* & caspase 8, apoptosis-related cysteine peptidase & 1.3 & 1.3 & 1.6 \\
\hline & CASPIO* & caspase 10, apoptosis-related cysteine peptidase & 2.9 & 2.6 & 2.6 \\
\hline & $\mathrm{BID}$ & $\mathrm{BH} 3$ interacting domain death agonist & 4.3 & 1.3 & 2.2 \\
\hline & $\mathrm{BCL} 2 *$ & B-cell CLL/lymphoma 2 & 0.6 & 0.7 & 0.7 \\
\hline & CYCS & cytochrome c, somatic & 1.0 & 0.7 & 0.8 \\
\hline & APAFI & apoptotic peptidase activating factor & 0.9 & 1.0 & 1.0 \\
\hline & CASP9 & caspase 9, apoptosis-related cysteine peptidase & 0.9 & 1.0 & 1.0 \\
\hline & CFLAR & CASP8 and FADD-like apoptosis regulator & 3.1 & 2.3 & 4.2 \\
\hline & FADD* & Fas (TNFRSF6)-associated via death domain & 0.8 & 1.0 & 0.9 \\
\hline & TRADD* & TNFRSFIA-associated via death domain & 2.1 & 2.0 & 1.3 \\
\hline & TRAF2 & TNF receptor-associated factor 2 & 1.1 & 0.9 & 0.6 \\
\hline & RIPKI* & receptor (TNFRSF)-interacting serine-threonine kinase I & 1.7 & I.I & 1.7 \\
\hline & MAP3KI4 & mitogen-activated protein kinase kinase kinase 14 & 1.6 & I.I & 1.9 \\
\hline & CHUK* & conserved helix-loop-helix ubiquitous kinase & 0.9 & 0.8 & 1.0 \\
\hline & NFKBIA* & $\begin{array}{l}\text { nuclear factor of kappa light polypeptide gene enhancer in B- } \\
\text { cells inhibitor, alpha }\end{array}$ & 12.6 & 6.6 & 10.5 \\
\hline & NFKBI* & $\begin{array}{l}\text { nuclear factor of kappa light polypeptide gene enhancer in B- } \\
\text { cells I (pI05) }\end{array}$ & 5.2 & 2.2 & 2.8 \\
\hline & $\mathrm{BIRC2*}$ & baculoviral IAP repeat-containing 2 & 1.5 & 1.0 & 1.7 \\
\hline & CASP3* & caspase 3 , apoptosis-related cysteine peptidase & 1.2 & 1.3 & 1.3 \\
\hline & CASP7* & caspase 7 , apoptosis-related cysteine peptidase & 3.4 & 2.1 & 2.7 \\
\hline & DFFB & $\begin{array}{l}\text { DNA fragmentation factor, } 40 \mathrm{kDa} \text {, beta polypeptide (caspase- } \\
\text { activated DNase) }\end{array}$ & 0.4 & 1.0 & 0.5 \\
\hline & DFFA & DNA fragmentation factor, $45 \mathrm{kDa}$, alpha polypeptide & 0.8 & I.I & 0.9 \\
\hline & CASP6* & caspase 6, apoptosis-related cysteine peptidase & 0.5 & 0.5 & 0.4 \\
\hline & LMNA & $\operatorname{lamin} \mathrm{A} / \mathrm{C}$ & 1.6 & 1.6 & 1.6 \\
\hline & GAS2 & growth arrest-specific 2 & 0.8 & 1.1 & 1.5 \\
\hline & SPTANI & spectrin, alpha, non-erythrocytic I (alpha-fodrin) & 1.3 & 1.3 & 0.9 \\
\hline \multirow[t]{19}{*}{ NF-kB Signaling Pathway } & TNFRSFIA & tumor necrosis factor receptor superfamily, member IA & 1.6 & 1.5 & 1.3 \\
\hline & FADD* & Fas (TNFRSF6)-associated via death domain & 0.8 & I.I & 0.9 \\
\hline & TRADD* & TNFRSFIA-associated via death domain & 2.1 & 2.0 & 1.3 \\
\hline & RIPKI* & receptor (TNFRSF)-interacting serine-threonine kinase I & 1.7 & I.I & 1.7 \\
\hline & TRAF6 & TNF receptor-associated factor 6 & 1.3 & 1.1 & 1.1 \\
\hline & TLR4 & toll-like receptor 4 & 1.3 & 1.2 & 0.9 \\
\hline & IRAKI & interleukin-I receptor-associated kinase I & 0.6 & 0.8 & 0.6 \\
\hline & MYD88 & myeloid differentiation primary response gene $(88)$ & 4.0 & 2.6 & 2.7 \\
\hline & ILIA & interleukin I, alpha & 3.2 & 1.2 & 2.4 \\
\hline & ILIB & interleukin I, beta & 63.2 & 17.5 & 53.1 \\
\hline & MAP3K7IPI & $\begin{array}{l}\text { mitogen-activated protein kinase kinase kinase } 7 \text { interacting } \\
\text { protein I }\end{array}$ & 0.7 & 1.0 & 0.8 \\
\hline & MAP3K7 & mitogen-activated protein kinase kinase kinase 7 & 1.1 & 0.9 & 0.9 \\
\hline & $\mathrm{CHUK}^{*}$ & conserved helix-loop-helix ubiquitous kinase & 0.9 & 0.8 & 1.0 \\
\hline & MAP3KI & mitogen-activated protein kinase kinase kinase I & 0.8 & 1.2 & I.I \\
\hline & MAP3KI4 & mitogen-activated protein kinase kinase kinase 14 & 1.6 & 1.1 & 1.9 \\
\hline & IKBKB & $\begin{array}{l}\text { inhibitor of kappa light polypeptide gene enhancer in B-cells, } \\
\text { kinase beta }\end{array}$ & 0.8 & 1.0 & 0.9 \\
\hline & IKBKG & $\begin{array}{l}\text { inhibitor of kappa light polypeptide gene enhancer in B-cells, } \\
\text { kinase gamma }\end{array}$ & 1.2 & 1.2 & 1.2 \\
\hline & NFKBIA* & $\begin{array}{l}\text { nuclear factor of kappa light polypeptide gene enhancer in B- } \\
\text { cells inhibitor, alpha }\end{array}$ & 12.6 & 6.6 & 10.5 \\
\hline & NFKBI* & $\begin{array}{l}\text { nuclear factor of kappa light polypeptide gene enhancer in B- } \\
\text { cells I (pI05) }\end{array}$ & 5.2 & 2.2 & 2.8 \\
\hline
\end{tabular}


Table 2: Differentially expressed genes of F3- or LPS-induced THP-I cells using oligonucleotide microarray (Continued)

\begin{tabular}{|c|c|c|c|c|c|}
\hline & RELA & $\begin{array}{l}\text { v-rel reticuloendotheliosis viral oncogene homolog A, nuclear } \\
\text { factor of kappa light polypeptide gene enhancer in B-cells } 3 \text {, } \\
\text { p65 (avian) }\end{array}$ & 1.0 & 1.1 & 1.1 \\
\hline \multirow{17}{*}{$\begin{array}{l}\text { TNFR2 Signaling } \\
\text { Pathway }\end{array}$} & LTA & lymphotoxin alpha & 1.4 & 1.7 & 1.2 \\
\hline & TNFRSFIB & tumor necrosis factor receptor superfamily, member IB & 4.3 & 3.5 & 4.1 \\
\hline & RIPKI* & receptor (TNFRSF)-interacting serine-threonine kinase I & 1.7 & I.I & 1.7 \\
\hline & TRAFI & TNF receptor-associated factor I & 5.9 & 4.4 & 7.9 \\
\hline & TRAF2 & TNF receptor-associated factor 2 & 1.1 & 0.9 & 0.6 \\
\hline & TRAF3 & TNF receptor-associated factor 3 & 1.3 & I.I & 1.2 \\
\hline & TANK & TRAF family member-associated NFKB activator & 2.3 & 1.9 & 2.9 \\
\hline & MAP3KI4 & mitogen-activated protein kinase kinase kinase 14 & 1.6 & I.I & 1.9 \\
\hline & MAP3KI & mitogen-activated protein kinase kinase kinase I & 0.8 & I.I & I.I \\
\hline & DUSPI & dual specificity phosphatase I & 2.7 & 1.5 & 4.0 \\
\hline & CHUK* & conserved helix-loop-helix ubiquitous kinase & 0.9 & 0.8 & 1.0 \\
\hline & IKBKB & $\begin{array}{l}\text { inhibitor of kappa light polypeptide gene enhancer in B-cells, } \\
\text { kinase beta }\end{array}$ & 0.8 & 0.9 & 0.9 \\
\hline & IKBKG & $\begin{array}{l}\text { inhibitor of kappa light polypeptide gene enhancer in B-cells, } \\
\text { kinase gamma }\end{array}$ & 1.2 & 1.2 & 1.2 \\
\hline & IKBKAP & $\begin{array}{l}\text { inhibitor of kappa light polypeptide gene enhancer in B-cells, } \\
\text { kinase complex-associated protein }\end{array}$ & 0.9 & 1.0 & 0.7 \\
\hline & TNFAIP3 & tumor necrosis factor, alpha-induced protein 3 & 12.7 & 5.4 & 11.4 \\
\hline & NFKBIA* & $\begin{array}{l}\text { nuclear factor of kappa light polypeptide gene enhancer in B- } \\
\text { cells inhibitor, alpha }\end{array}$ & 12.2 & 6.6 & 10.5 \\
\hline & NFKBI* & $\begin{array}{l}\text { nuclear factor of kappa light polypeptide gene enhancer in B- } \\
\text { cells I (pI05) }\end{array}$ & 5.2 & 2.2 & 2.8 \\
\hline \multirow{26}{*}{$\begin{array}{l}\text { Toll-like Receptor } \\
\text { Pathway }\end{array}$} & TLR2 & toll-like receptor 2 & 1.2 & 2.1 & 2.6 \\
\hline & CDI4 & CDI4 antigen ; CDI4 antigen & 0.5 & 15.2 & 16.9 \\
\hline & MYD88 & myeloid differentiation primary response gene (88) & 4.0 & 2.6 & 2.7 \\
\hline & TLR4 & toll-like receptor 4 & 1.3 & 1.2 & 0.9 \\
\hline & LY96 & lymphocyte antigen 96 & 0.6 & 5.3 & 6.3 \\
\hline & TOLLIP & toll interacting protein & 1.0 & 1.1 & 1.2 \\
\hline & IRAKI & interleukin-I receptor-associated kinase I & 0.6 & 0.8 & 0.6 \\
\hline & TRAF6 & TNF receptor-associated factor 6 & 1.3 & I.I & I.I \\
\hline & EIF2AK2 & eukaryotic translation initiation factor 2-alpha kinase 2 & 5.1 & 4.0 & 4.5 \\
\hline & SITPEC & $\begin{array}{l}\text { signaling intermediate in Toll pathway, evolutionarily } \\
\text { conserved }\end{array}$ & 0.8 & 0.7 & 0.4 \\
\hline & MAP3KI & mitogen-activated protein kinase kinase kinase I & 0.8 & 1.2 & 1.1 \\
\hline & $\mathrm{CHUK}^{*}$ & conserved helix-loop-helix ubiquitous kinase & 0.9 & 0.8 & 1.0 \\
\hline & IKBKB & $\begin{array}{l}\text { inhibitor of kappa light polypeptide gene enhancer in B-cells, } \\
\text { kinase beta }\end{array}$ & 0.8 & 1.0 & 0.9 \\
\hline & IKBKG & $\begin{array}{l}\text { inhibitor of kappa light polypeptide gene enhancer in B-cells, } \\
\text { kinase gamma }\end{array}$ & 1.2 & 1.2 & 1.2 \\
\hline & NFKBIA* & $\begin{array}{l}\text { nuclear factor of kappa light polypeptide gene enhancer in B- } \\
\text { cells inhibitor, alpha }\end{array}$ & 12.6 & 6.6 & 10.5 \\
\hline & MAP3K7 & mitogen-activated protein kinase kinase kinase 7 & I.I & 0.9 & 1.0 \\
\hline & MAP3K7IP2 & $\begin{array}{l}\text { mitogen-activated protein kinase kinase kinase } 7 \text { interacting } \\
\text { protein } 2\end{array}$ & 1.6 & 1.2 & 1.4 \\
\hline & MAP3K7IPI & $\begin{array}{l}\text { mitogen-activated protein kinase kinase kinase } 7 \text { interacting } \\
\text { protein I }\end{array}$ & 0.7 & 1.0 & 0.8 \\
\hline & MAP2K3 & mitogen-activated protein kinase kinase 3 & 2.2 & 1.5 & 1.9 \\
\hline & MAP2K6 & mitogen-activated protein kinase kinase 6 & 0.7 & 1.1 & 0.8 \\
\hline & MAPKI4 & mitogen-activated protein kinase 14 & 0.6 & 0.9 & 0.8 \\
\hline & MAP2K 4 & mitogen-activated protein kinase kinase 4 & 0.9 & 1.0 & 1.0 \\
\hline & MAPK8 & mitogen-activated protein kinase 8 & 2.6 & 1.2 & 1.5 \\
\hline & JUN & v-jun sarcoma virus 17 oncogene homolog (avian) & 7.9 & 1.3 & 2.6 \\
\hline & FOS & v-fos FBJ murine osteosarcoma viral oncogene homolog & 1.5 & 2.3 & 1.8 \\
\hline & ELKI & ELKI, member of ETS oncogene family & 0.9 & 1.4 & 1.5 \\
\hline
\end{tabular}

*These genes have been validated by Q-PCR. 


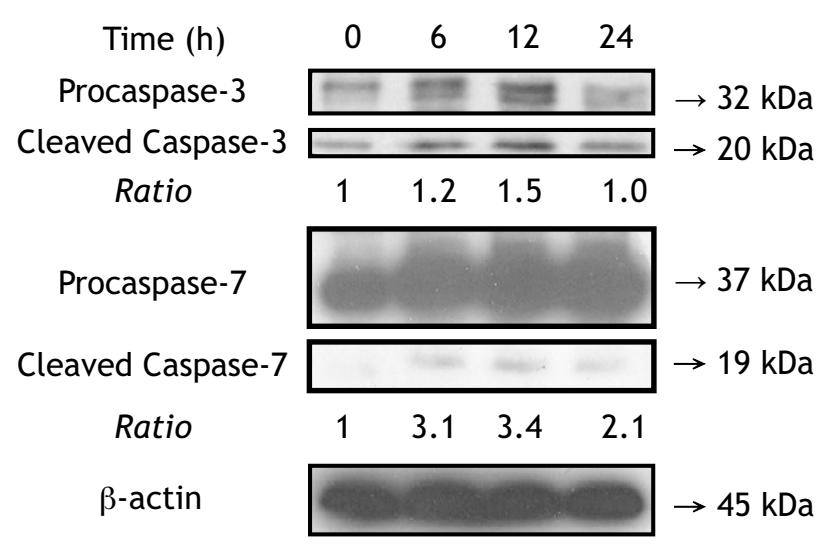

\section{Figure 6}

CASP3 and CASP 7 were cleaved into active forms after F3 treatment in THP-I cells. After THP-I cells were treated with F3 for 0, 6, 12, 24 hours, we detected proforms and active forms of CASP3 and CASP7 using western blotting. CASP3 and CASP7 were activated after F3 treatment.

1 cells. TRAF1 is an adapter protein and signal transducer that links members of the TNFR family to different signaling pathways by association with the receptor cytoplasmic domain and kinases. TRAF1 is involved in apoptosis by mediating the activation of NF- $\kappa \mathrm{B}$ and c-Jun N-terminal kinase (JNK) [51]. TRAF family member-associated NF- $\kappa B$ activator (TANK) acts as a regulator of TRAF function by maintaining TRAF in a latent state. Alpha-induced protein 3 (TNFAIP3), a tumor necrosis factor, was induced by TNF- $\alpha$ and identified as a regulatory component of a putative cytoplasmic signaling cascade that mediates NF- $\kappa \mathrm{B}$ activation in response to DNA damage [52].

Toll-like receptor pathway was observed to be significant ( $\mathrm{p}<0.05$ and $\mathrm{q}<0.05$ ) in LPS-treated but not in F3treated THP-1 cells (Table 1). This pathway includes 27 genes among which six and seven genes were differentially expressed in F3- and LPS-treated THP-1 cells, respectively. After F3 treatment for six hours, MYD88, eukaryotic translation initiation factor 2-alpha kinase 2 (EIF2AK2), NFKBLA, mitogen-activated protein kinase kinase 3 (MAP2K3), mitogen-activated protein kinase 8 (MAPK8) and v-Jun sarcoma virus 17 oncogene homolog (avian) (JUN) were up-regulated and CD14 antigen (CD14) was down-regulated. Interestingly, CD14 was up-regulated after treatments with LPS and F3 for 24 hours. CD14 cooperates with TLR4 to mediate the innate immune response to LPS and acts via MYD88 and TRAF6, leading to NF- $\kappa$ B activation, cytokine secretion and the inflammatory response. Lymphocyte antigen 96 (LY96) was up-regulated after treatment with F3 or LPS for 24 hours. The downstream signaling pathway used by toll-like receptors are similar to that used by IL-1 receptors, which is activat- ing the IL-1 receptor associated kinase (IRAK) through the MYD88 adaptor protein, and signaling through TRAF- 6 and protein kinase cascades to activate NF- $\kappa \mathrm{B}$ and Jun [53]. In conclusion, the expression of these genes in the toll-like receptor pathway may implicate their associations with THP-1 apoptosis after F3 or LPS treatment.

\section{Comparisons between oligonucelotide microarray and Q- PCR results}

To further validate our findings from the microarray analysis, we selected a set of genes known for their involvement in apoptosis through death receptors, and carried out gene expression studies using Q-PCR. 18 gene expressions related to the death receptor pathway were examined between F3- or LPS-treated THP-1 cells for 3, 6, 12, and 24 hours. mRNAs were reverse-transcribed and amplified through Q-PCR using primers specific for each gene of interest; the housekeeping gene, GAPDH, was used as internal control. Each experiment was repeated three times. The results are shown in Figure 7 and 8. Significance analysis of Q-PCR measurements was performed by EDGE software package [54]. There were nine significantly differential gene expressions in F3-treated THP-1 cells, including TNFRSF10B, CASP7, CASP6, TRADD, CASP3, TNFSF12, baculoviral IAP repeat-containing 2 (BIRC2/c-IAP), conserved helix-loop-helix ubiquitous kinase (CHUK/IKK $\alpha$ ), and NF- $\kappa \mathrm{B}$ (NFKB1); whereas in LPS-treated THP-1 cells these were TNFRSF12, CASP7, TNFSF12, CASP6, TRAF2, and NFKB1. Figure 9 shows that nearly all genes are consistent between the microarray and Q-PCR data.

We compared the 18 gene expressions in the time courses after F3 or LPS treatments, as shown in Figure 7 and 8. Statistically significant difference of time-course gene expression profiles between F3 and LPS treatment was observed for TRADD, CHUK, TRAF2, BIRC2, TNFSF10, FADD, CASP3, CASP10, CASP6, BCL2, and NFKB1, while other genes exhibited similar expression trends. These results suggest that THP-1 cells have similar but different gene expression response to F3 and LPS treatments.

\section{Construction of cell death gene networks and possible pathways involved in F3-induced THP-I cell death}

Based on our time-course Q-PCR data, we constructed the cell death gene network in F3-treated THP-1 cells by our self-developed software tool, BSIP [55]. Assuming that gene regulatory network follows the S-system mathematical model [56], we used BSIP to estimate the modeling parameters, identify the optimized structure, compare the concordance, and infer a plausible regulatory network. Moreover, we established the interrelated apoptosis pathways initiated by F3 in THP-1 cells using our concurrent findings, as illustrated in Figure 10. Death receptors, which belong to tumor necrosis factor (TNF) gene super- 

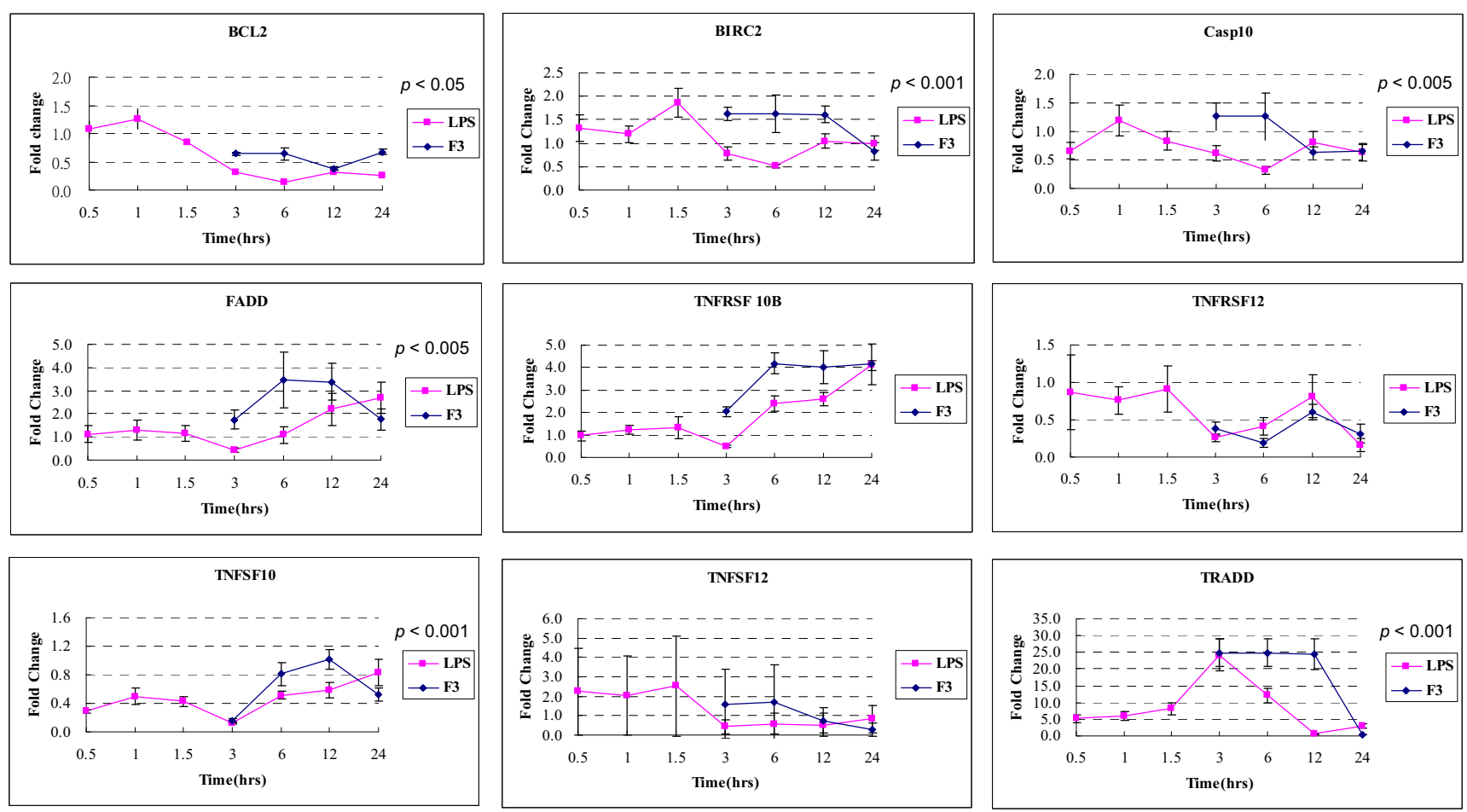

\section{Figure 7}

Fold change in time-course gene expression of F3- or LPS-induced THP-I cells by Q-PCR. First, THP-I cells were treated with F3 or LPS for different periods of time and were collected at different time points. Total RNA was isolated from cell lines using TRIzol reagent. First-strand cDNA synthesis were performed with $5 \mu \mathrm{g}$ of total RNA in a volume of $20 \mu \mathrm{l}$ with I $\mu \mathrm{l}$ ThermoScript ${ }^{\mathrm{TM}}$ Reverse Transcriptase (Invitrogen) and I $\mu$ loligo(dT). Extracted first-strand cDNAs were analyzed using BioRad iCycler iQ Real-Time Detection System with SYBR Green dye (Molecular Probes, Eugene, OR). Software designed for the BioRad iCycler will aid in analyzing collected data. mRNA expression of these genes were normalized to RNA content for each sample by using GADPH gene products as internal controls. Relative expression was calculated as the ratio of expression from each F3-treated THP-I cells in comparison to untreated THP-I cells (control). The error bar came from $n>3$. The $p$ values indicate the statistical significance of different time-course gene expression profiles between F3 and LPS treatment.

family, are cell surface receptors that transmit apoptosis signals and play a crucial role in apoptosis and cell survival. Our characterized death receptors are TNFR1 (tumor necrosis factor receptor-1), TNFR2 (tumor necrosis factor receptor-2), and DR4/5 (also called TRAIL-R1/2) [31]. TNF- $\alpha$ and TNFSF10, also called TRAIL, exhibit an increase in gene expression in F3-treated THP-1 cells. When TNF- $\alpha$ binds to TNFR1, adaptor protein TRADD recruitment follows, and then it interacts with another death domain-containing molecule FADD, leading to the subsequent cleavage of pro-caspase-8 [57]. The binding of TRAIL to DR4/5 also induces the recruitment of FADD and pro-caspase- 8 of auto-proteolytic activation [37]. Interactions between pro-caspase- 8 and FADD result in further activation of caspase- 3 and caspase-7, and also the initiation of apoptosis [58]. In addition to apoptotic signals, recruitment of TRAF2 through TNFR2 binding TNF$\alpha$ activates NF- $\kappa \mathrm{B}$, thus producing anti-apoptotic signals
[59]. TNFR1 also activates anti-apoptotic NF- $\kappa$ B. NF- $\kappa$ Bdependent activation of TRAF2, RIPK1, and BIRC2 gene expressions seemed to support this because TRAF2 and RIP interacting with TRADD prevented caspase- 8 activation, while c-IAPs inhibited caspase- 3 and caspase- 7 activation [60]. When NF- $\kappa \mathrm{B}$ is activated, $\mathrm{I} \kappa \mathrm{B}$ is phosphorylated by protein kinase IKK and this phosphorylation serves as a signal for the ubiquitination and degradation of $\mathrm{I} \kappa \mathrm{B}$. Free NF- $\kappa \mathrm{B}$ dimers are released and translocated to the nucleus, where they enhance the transcription of target genes. NF- $\kappa \mathrm{B}$ activation and $\mathrm{I} \kappa \mathrm{B}$ degradation prompt cell survival signals and mediate immune responses [61]. In contract, NF- $\kappa \mathrm{B}$ is a transcription factor that regulates expression of a large number of genes critical for the regulation of apoptosis, and many reports have showed that Apo2L/TRAIL can activate NF- $\kappa$ B $[29,49]$. All in all, NF- $\kappa$ B activation can promote apoptosis or survival, depending on the cellular contents [49]. 

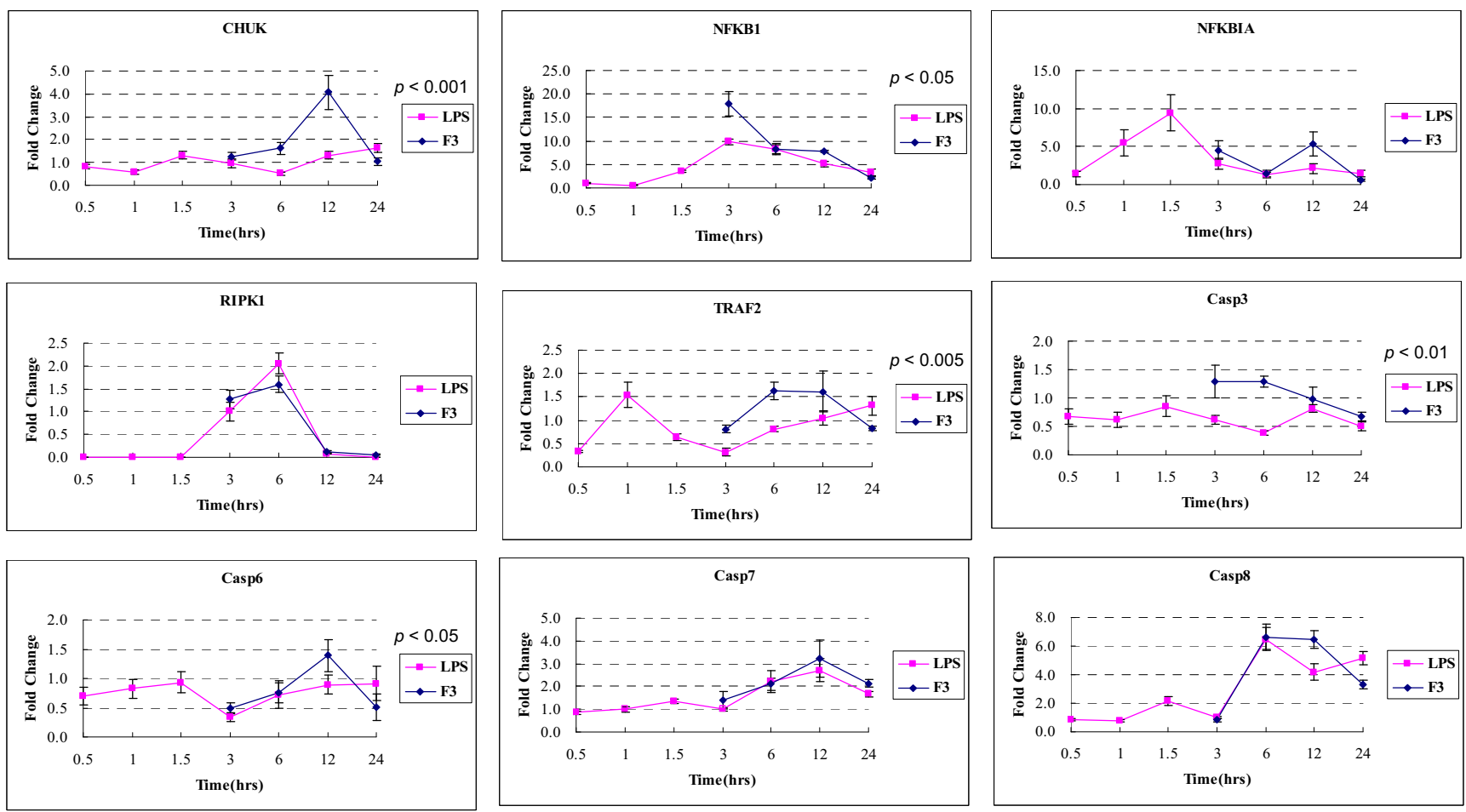

Figure 8

Fold change in time-course gene expression of F3- or LPS-induced THP-I cells by Q-PCR. (continued from Figure 7)

\section{Conclusion}

In conclusion, we performed time-course microarray analysis and Q-PCR assays for measuring gene expression profiles of F3-treated THP-1 cells. Integrating the expression data, we applied computational modeling to infer plausible gene regulatory networks involved in F3induced cell death. Our results suggested that F3 might mimic/induce death receptor ligands such as TNF- $\alpha$ and TRAIL to initiate signaling via death receptor oligomerization, recruitment of specialized adaptor proteins, and the activation of caspase cascade, followed by cell shrinkage and apoptosis. This study confirmed microarray analysis to be a powerful tool for demonstrating gene expressions related to the efficacy of anti-tumor drugs such as Ganoderma lucidum polysaccharides, F3, on tumor growth. This approach opens a different way of elucidating the molecular mechanisms for anti-tumor compounds or drugs in cancer cells. Information in this study may present a powerful tool for cancer diagnosis and therapy.

\section{Methods}

\section{Materials}

Crude Reishi extract (prepared via alkaline extraction $(0.1 \mathrm{~N} \mathrm{NaOH})$, neutralization and ethanol precipitation) was obtained from Pharmanex Co. (CA, USA). All chemi- cals and reagents were from Sigma-Aldrich Co., unless indicated.

\section{Purification of Reishi extract}

Crude Reishi powder (obtained from Pharmanex Co.) $6 \mathrm{~g}$ was dissolved in $120 \mathrm{~mL}$ of dd water, stirred at $4{ }^{\circ} \mathrm{C}$ for 1 hour, and centrifuged (1000 rpm) for 1 hour to remove the insoluble. The resulting solution was concentrated at $40 \sim 50^{\circ} \mathrm{C}$ to give a small volume which then was lyophilized to generate $5 \mathrm{~g}(83 \%)$ powder of dark-brown color. This water soluble residue was stored at $-20^{\circ} \mathrm{C}$ for further purification.

\section{Isolation of the F3 fraction of Reishi polysaccharide [8]}

F3 was isolated from the dark powder of water soluble residue of Reishi polysaccharide. The procedure during chromatography was maintained at $4{ }^{\circ} \mathrm{C}$ in cool room. The 2.1 $\mathrm{g}$ sample was dissolved in a small volume of Tris buffer (pH7.0, $0.1 \mathrm{~N}$ ) containing $0.1 \%$ sodium azide, and purified by gel filtration chromatography using a Sephacryl S500 column $(95 \times 2.6 \mathrm{~cm})$ with $0.1 \mathrm{~N}$ Tris buffer $(\mathrm{pH} 7.0)$ as the eluent. The flow rate was set at $0.6 \mathrm{~mL} / \mathrm{min}$, and 6.0 $\mathrm{mL}$ per tube was collected. After the chromatography, each fraction was subjected to phenol- $\mathrm{H}_{2} \mathrm{SO}_{4}$ method to detect the content of sugar in each tube. Five fractions were collected (fractions 1-5), F3 fraction was concen- 

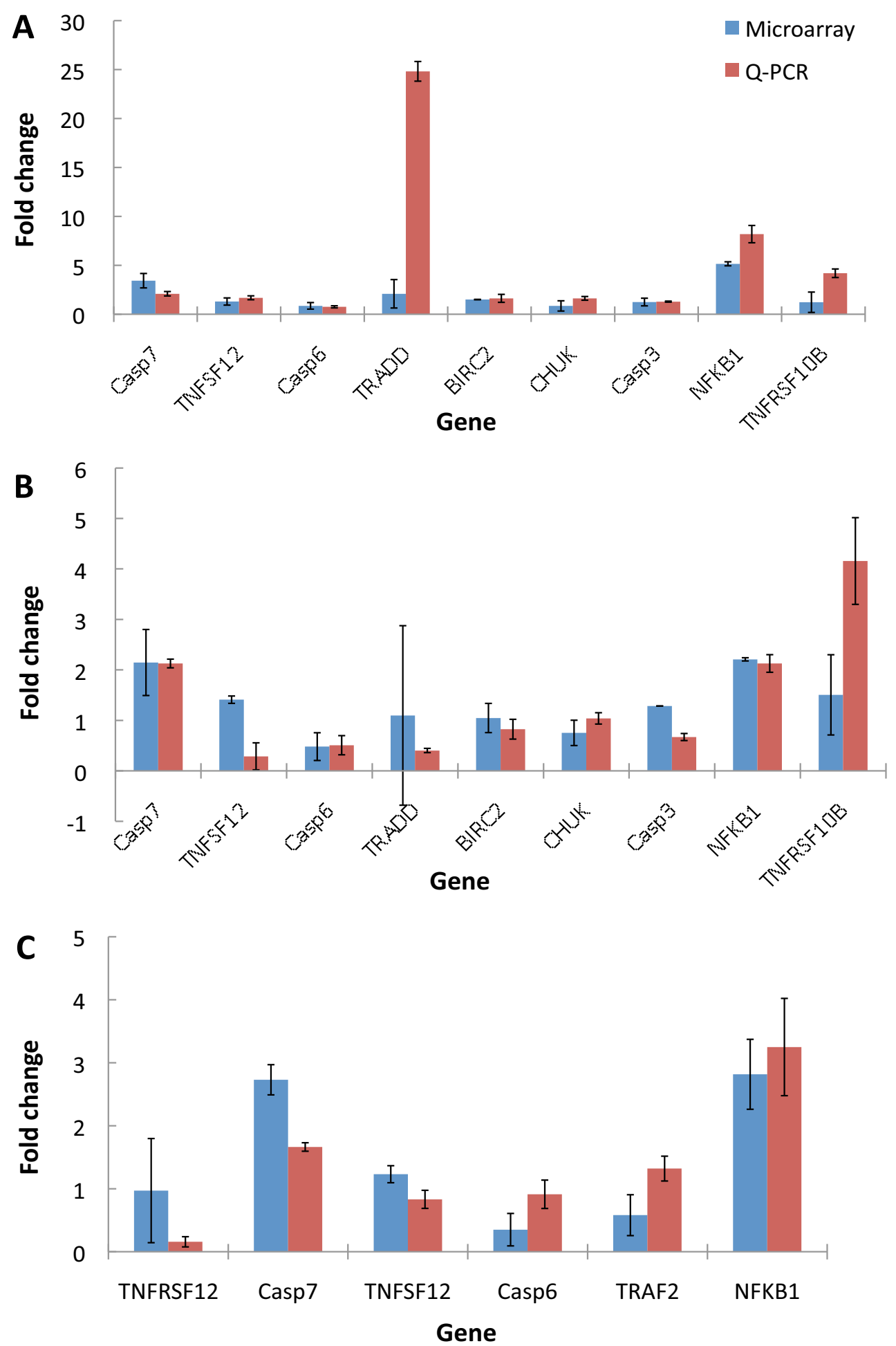

Figure 9

Comparisons between oligonucelotide microarray and Q-PCR results. (A) THP-I cells were treated with F3 for 6 hours (A) and 24 hours (B) and with LPS for 24 hours (C). The gene expressions showed consistent trends between the microarray and Q-PCR results. The error bar came from $n>3$. 


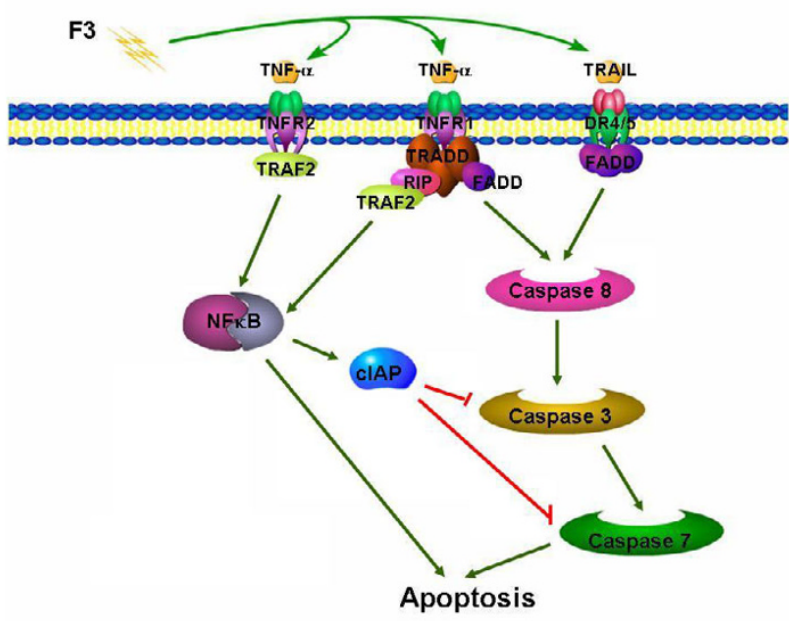

Figure 10

Proposed F3-induced cell death pathways in THP-I cells. Based on our self-developed software for the reconstruction of gene networks in addition to literature research, we proposed plausible cell death pathways induced by F3 in THP-I cells. F3 may induce death receptor ligands (TNF- $\alpha$ and TRAIL) to initiate signaling via receptor oligomerization, recruitment of specialized adaptor proteins and activation of caspase cascades. Lastly, cell shrinkage and apoptosis occur.

trated at $40 \sim 50^{\circ} \mathrm{C}$ to give a small volume in rotary vapor, which was dialyzed or purified through G-50 column to remove excessive salt and sodium azide and was then lyophilized to give $520 \mathrm{mg}$ (25\%) of F3.

\section{THP-I cell culture and induction of cell death}

The monocyctic cell-line THP-1 cells were seeded at an initial concentration of $10^{5}$ cells/mL in RPMI 1640 Medium supplemented with $2 \mathrm{mg} / \mathrm{mL}$ sodium bicarbonate (Atlanta Biologicals, GA, USA), $4.5 \mathrm{mg} / \mathrm{mL}$ glucose, $2 \mathrm{mg} /$ mL HEPES, 1\% Antibiotic-antimycotic, 10\% serum fetal bovine. Cells were cultured at $37^{\circ} \mathrm{C}$ in an incubator with controlled humidified atmosphere containing 5\% $\mathrm{CO}_{2}$. We detected apoptotic cells by 4,6-diamidino-2-phenylindole (DAPI; Sigma, St. Louis, MO, USA) staining. After washing with PBS and fixing with $4 \%$ paraformaldehyde for $15 \mathrm{~min}$, the cells were stained with $2 \mathrm{mg} / \mathrm{mL}$ DAPI for $20 \mathrm{~min}$. The stained cells were examined under a fluorescent microscope and cells were considered to undergo apoptosis based on the appearance of nuclear fragmentation.

\section{Detection of TNF- $\alpha$ activity by colorimetric sandwich ELISA}

The induction agent, lipopolysaccharide (LPS) or F3, was dissolved in RPMI 1640 Medium at a stock concentration of $4 \mathrm{mg} / \mathrm{mL}$ and $2 \mathrm{mg} / \mathrm{mL}$, respectively; then stored at $20^{\circ} \mathrm{C}$. THP- 1 cells with $10^{5}$ cells $/ \mathrm{mL}$ concentrations were seeded in 96-well microplates and incubated overnight. Then the cells $\left(1.25 \times 10^{4}\right)$ were treated with F3 at the dosages indicated as $1 \mu \mathrm{g} / \mathrm{mL}, 10 \mu \mathrm{g} / \mathrm{mL}, 50 \mu \mathrm{g} / \mathrm{mL}, 100 \mu \mathrm{g} /$ $\mathrm{mL}, 200 \mu \mathrm{g} / \mathrm{mL}$, and with LPS at the dose of $1 \mu \mathrm{g} / \mathrm{mL}$, respectively. The same volume of medium was applied as control. After 24 hours, the supernatants were collected at indicated time points by centrifugation at $1200 \mathrm{~g}$ for 5 min. In vitro TNF- $\alpha$ activity was determined using Human TNF- $\alpha$ Immunoassay Kit (Quantikine ${ }^{\circledast}, \mathrm{RD}$ systems) based on the manual provided. The procedure is briefly described as follows. Assay Diluent RD1F solution (50 $\mu \mathrm{L})$ and $200 \mu \mathrm{L}$ of sample supernatants, standard and control, were gently mixed and loaded into individual wells. After 2 hours of incubation at room temperature, each well was aspirated, washed three times with $400 \mu \mathrm{L}$ of Wash Buffer, loaded with $200 \mu$ of secondary antibody solution (TNF$\alpha$ Conjugate solution) at room temperature for 1 hour. The same aspiration and wash procedures were performed; $200 \mu \mathrm{L}$ of substrate solution was then added to each well and incubated in darkness at room temperature for $20 \mathrm{~min}$. The enzymatic reaction was finally terminated by the addition of $50 \mu \mathrm{l}$ of Stop Solution. The optical density was determined using a microplate ELISA reader (Molecular Devices Corporation, California, USA) set at $450 \mathrm{~nm}$ with the correction wavelength at 540 or $570 \mathrm{~nm}$. The concentration of TNF- $\alpha$ was determined by plotting the sample reading against the standard curve. All the measurements were performed in triplicate.

\section{Microarray gene expression analysis}

THP-1 cells with $10^{7}$ cells/mL concentrations were seeded in $100 \mathrm{~mm}$ dish and incubated overnight. After that, cells were treated with F3 and LPS at a final concentration of 30 $\mu \mathrm{g} / \mathrm{mL}$ and $1 \mu \mathrm{g} / \mathrm{mL}$, respectively. After incubated for 6 and 24 hours, the cell pellets were collected by centrifugation at $250 \mathrm{~g}$ for $5 \mathrm{~min}$, correspondingly. Controlled samples of un-induced cells were treated in the same way with the same amount of medium. Total cellular RNA was extracted from a minimum of $5 \times 10^{6}$ cells with the use of TRIzol reagent (Invitrogen Life Technologies, Carlsbad, CA, USA); RNA was additionally purified with phenolchloroform-isoamylalcohol $(25: 24: 1)$. Purity was confirmed by spectrophotometry $\left(\mathrm{A}_{260} / \mathrm{A}_{280}\right.$ ratio $)$ and capillary electrophoresis (Agilent 2100 Bioanalyzer, Agilent Inc, Foster City, CA). RNA processing and hybridization onto Affymetrix (Santa Clara, CA) HG-U133A GeneChip oligonucleotide microarray were performed according to the manufacturer's protocol. Initial data analysis was performed using Affymetrix Microarray Suite v5.0 software, setting the scaling of all probe sets to a constant value of 500 for each GeneChip. Additional data analysis was performed using GeneSpring v5.1 (Silicon Genetics Inc., Redwood City, California). Principle component analysis on gene expression profiles of control ( 0 and 6 hours) and F3-treated ( 6 and 24 hours) samples were performed 
using Cluster 3.0 [62]. Genes with 2-fold change in differential expression between THP-1 control (combining 0 and 6 hours in total of four arrays) and F3- or LPS-treated THP-1 cells were selected for further analysis. Based on fold-change expression, genes that were differentially expressed between the two repeated microarray experiments were subjected to a scatter-plot analysis.

\section{Functional classification of differentially expressed genes} The differentially expressed genes were classified into groups based on their annotated functions using the BGSSJ software tool [63]. BGSSJ is an XML-based Java application that organizes lists of genes or proteins according to Gene Ontology database for biological interpretation [64], and organizes information based on molecular functions, biological processes, and cellular components for a number of different organisms. For our transcriptomic data, the UniGene IDs of the differentially expressed genes were used to input into BGSSJ with a database option of "NCBI + GO".

\section{Biological pathway annotations}

The differentially expressed genes were annotated to specific biological pathways. For each UniGene ID, we retrieved its biological pathways from either BioCarta [44] or KEGG [45] through the existing NCI CGAP gene information database [46]. Biological pathways were mapped and sorted on the order of matching significance using the ArrayXPath web tool [47].

Table 3: Primer sequences in Q-PCR experiments

\begin{tabular}{|c|c|c|}
\hline Gene Name & Primer Sequence & PCR products \\
\hline \multicolumn{3}{|l|}{ Sense Primer } \\
\hline BCL2-S & CGATGTGATGCCTCTGCGAAG & $95 \mathrm{bp}$ \\
\hline $\mathrm{BCL2}-\mathrm{A}$ & GCCATGCTGATGTCTCTGGAATC & \\
\hline BIRC2-S & GTTCCAGTTCAGCCTGAGCAG & 102 bp \\
\hline BIRC2-A & ССААСАССТСAAGCCACCATC & \\
\hline CASPIO-S & CACAGTCCACCСACССТСТС & 132 bp \\
\hline CASPIO-A & СTTCCTATGTGAGCACCTTCCTTAC & \\
\hline FADD-S & ACAGCATCGAGGACAGATACCC & $96 \mathrm{bp}$ \\
\hline FADD-A & CCACTGTTGCGTTCTCСTTCTC & \\
\hline TNFRSFIOB-S & GCACCACGACCAGAAACACAG & $124 \mathrm{bp}$ \\
\hline TNFRSFIOB-A & CAATCACCGACCTTGACCATCC & \\
\hline TNFRSFI2-S & TCAGCCAATGTGTCAGCAGTTC & $150 \mathrm{bp}$ \\
\hline TNFRSFI2-A & CGCAGCCATCGCCATGTTC & \\
\hline TNFSFIO-S & GCTGAAGCAGATGCAGGACAAG & 136 bp \\
\hline TNFSFIO-A & CTGACGGAGTTGCCACTTGAC & \\
\hline TNFSFI2-S & TCAACAGCTCCAGCССTCTG & 146 bp \\
\hline TNFSFI2-A & CACACCATCCACCAGCAAGTC & \\
\hline TRADD-S & TTTGCTGGCGGACGAGGAG & $119 \mathrm{bp}$ \\
\hline TRADD-A & CCGAGCCGCACTTCAGATTTC & \\
\hline CHUK-S & GCCATCCACTATGCTGAGGTTG & $140 \mathrm{bp}$ \\
\hline CHUK-A & GCACGCTGTTCCAGAGATTCC & \\
\hline NFKBI-S & CTCAAAGCAGCAGGAGCAGATC & $71 \mathrm{bp}$ \\
\hline NFKBI-A & TCCCAAGAGTCATCCAGGTCATAG & \\
\hline NFKBIA-S & AGTGATCCGCCAGGTGAAGG & $130 \mathrm{bp}$ \\
\hline NFKBIA-A & ACAGCCAGCTCCCAGAAGTG & \\
\hline RIPKI-S & AAGTGGGTGATGAGGGAAGGC & $80 \mathrm{bp}$ \\
\hline RIPKI-A & TCGATCCTGGAACACTGGTGG & \\
\hline TRAF2-S & AACATTGTCTGCGTCCTGAACC & 159 bp \\
\hline TRAF2-A & AGCCATCGCCAGGTCCTTG & \\
\hline Casp3-S & ATGGACCACGCAGGAAGGG & $68 \mathrm{bp}$ \\
\hline Casp3-A & GGCAGCATCATCCACACATACC & \\
\hline Casp6-S & GCCACGCAGATGCCGATTG & 139 bp \\
\hline Casp6-A & CCAACCAGGCTGTGACACTTG & \\
\hline Casp7-S & GTCTCACCTATCCTGCCCTCAC & 114 bp \\
\hline Casp7-A & TTCTTСTССТGССТСАСТGTCC & \\
\hline Casp8-S & GAAAAGCAAACCTCGGGGATAC & $113 \mathrm{bp}$ \\
\hline Casp8-A & CCAAGTGTGTTCCATTCCTGTC & \\
\hline GAPDH-S & ACACCСАСТССТССАССТTTG & $98 \mathrm{bp}$ \\
\hline GAPDH-A & GCTGTAGCCAAATTCGTTGTCATAC & \\
\hline
\end{tabular}

"S" means sense strand; "A" means anti-sense strand. 


\section{Statistical analysis for identification of significantly disturbed pathways}

The disturbed pathways with statistical significance were identified based on Fisher's exact test and false discovery rate. The statistical analysis was performed using ArrayXPath.

\section{Primer design}

Primers were designed based on the published sequences in NCBI. We used Beacon Designer [65] to design the primers. Primers were designed to meet the following requirements: $75-150$ bp in length, $50-60 \%$ in CG content, less than 5 degrees Tm difference between forward and reverse primers, limited GC repeats, amplicons between $80-120 \mathrm{bp}$, and limited dimer and hairpin formation. The designed primers are shown in Table 3.

\section{Quantitative real-time $P C R$}

Gene expression of the genes in death receptor pathway was determined by RT-PCR. Total RNA were isolated from cell lines using TRIzol reagent according to the manufacturer's protocol. First-strand cDNA synthesis was performed on $5 \mu \mathrm{g}$ of total RNA in a volume of $20 \mu \mathrm{l}$ with 1 $\mu \mathrm{l}$ ThermoScript ${ }^{\mathrm{TM}}$ Reverse Transcriptase (Invitrogen) and $1 \mu \mathrm{l}$ oligo(dT). Extracted first-strand cDNAs were analyzed using a BioRad iCycler iQ Real-Time Detection System with SYBR Green dye (Molecular Probes, Eugene, OR). SYBR Green yields a strong fluorescent signal on binding double-stranded DNA enabling the quantification of gene expression by measurement of the intensity of the fluorescent light. SYBR Green will bind to any PCR product amplified by primers and is therefore, non-specific and less accurate than designing specialized probes. Targeted products were between 100-200 bp. For each experimental setup, a standard curve was prepared consisting of 5 dilutions of PCR products. Software produced for the BioRad iCycler will aid in evaluating collected data. mRNA expression of these genes were normalized to RNA content for each sample by using GADPH gene products as internal controls. The relative expression was calculated as the ratio of expression from each F3-treated THP-1 cells compared with the control THP-1 cells.

\section{Significance analysis of Q-PCR experiments}

Significance analysis of Q-PCR experiments was performed by the EDGE software tool $[54,66]$. EDGE is based on Optimal Discovery Procedure, a new method that finds the optimal rule for calling differentially expressed genes, and Time Course Methodology.

\section{Western blotting}

F3-treated and untreated THP-1 cells were washed with PBS twice. Cell pellets $\left(1 \times 10^{7}\right.$ cells $)$ were solubilized in lysis buffer containing $7 \mathrm{M}$ urea, 4\% CHAPS, $2 \mathrm{M}$ thiourea, and $0.002 \%$ bromophenol blue. Lysates were centrifuged at $13,200 \times \mathrm{g}$ for $30 \mathrm{mins}$. Proteins were loaded into $10 \%$ SDS-PAGE and transferred onto polyvinylidene difluoride membranes (Millipore, Bedford, MA) at $150 \mathrm{~V}$ for 1.5 hours. After blocking in 5\% nonfat milk in PBST containing $0.05 \%$ Tween 20 (Sigma) at room temperature overnight with gentle rocking, membranes were probed with antibodies. Primary antibodies involved in this study include CASP3 (IMGENEX, San Diego, CA) and CASP7 (Upstate, Lake Placid, NY) diluted in 1:200 and 1:300, respectively. Membranes were incubated with corresponding primary antibody and then incubated with secondary antibodies (biotinylated anti-mouse IgG-HRP, 1:2000 dilution, Abcam, Cambridge, UK). After incubation with secondary antibodies, immunoblots were visualized with the ECL detection kit (Amersham Biosciences) and exposed to X-ray film. $\beta$-actin was used as an internal loading control.

\section{Network construction}

Based on the time-course Q-PCR data, we reconstructed a plausible gene regulatory network in F3-treated THP-1 cells using the BSIP web tool [55]. We developed BSIP to solve the reverse engineering problems for gene regulatory network or other biological networks. BSIP is a PHP-based web server for identification of biological networks using experimental time-series data obtained from microarray, Q-PCR, proteomics, or metabolomics measurements. Based on the S-system modeling formalism, $\dot{X}_{i}=\alpha_{i} \prod_{j} X_{j}^{g_{i j}}-\beta_{i} \prod_{j} X_{j}^{h_{i j}}$, where $X_{i}$ represents the gene expression level and $\alpha_{j^{\prime}} \beta_{j^{\prime}} g_{i j^{\prime}}$ and $h_{i j}$ represent the regulatory parameters, an evolutionary optimization method with data collocation [56] was used to estimate the modeling parameters with the measured time-series data of gene expression and determine the regulatory network structure.

\section{Authors' contributions}

KCC carried out cell culture, detection of TNF- $\alpha$ activity, Q-PCR and microarray experiments. KCC, $\mathrm{HCH}, \mathrm{JHC}$, JWH, HCC and HFJ undertook microarray data analysis. $\mathrm{HCH}$ and $\mathrm{CHO}$ constructed the gene network and biological pathways. JWH, carried out the western blotting and DAPI experiments. WBY, STC and CHW purified and provided F3 polysaccharides. $\mathrm{HCH}$ and HFJ designed the study. HFJ, drafted the manuscript, conceived and directed the project. All authors read and approved the final manuscript.

\section{Acknowledgements}

This research supported by National Science Council of Taiwan (NSC 95222I-E-002-183), NTU Frontier and Innovative Research Projects (NTUPFIR-95R0 107) and The Thematic Research Program, Academia Sinica, Tai- 
wan (AS-94-TP-BI0). We thank Chi-Chin Chang for assisting in the statistical calculation and Jason Lee for proofreading the manuscript.

\section{References}

I. Chui $\mathrm{CH}$, Wong RS, Cheng GY, Lau FY, Kok SH, Cheng $\mathrm{CH}$, Cheung F, Tang WK, Teo IT, Chan AS, et al.: Antiproliferative ability of a combination regimen of crocodile egg extract, wild radix ginseng and natural Ganoderma lucidum on acute myelogenous leukemia. Oncol Rep 2006, I6(6): I3 I3-13 |6.

2. Kashimoto N, Hayama M, Kamiya K, Watanabe H: Inhibitory effect of a water-soluble extract from the culture medium of Ganoderma lucidum (Rei-shi) mycelia on the development of pulmonary adenocarcinoma induced by $\mathbf{N}$-nitrosobis (2hydroxypropyl) amine in Wistar rats. Oncol Rep 2006, I6(6): $1181-1187$.

3. Yue GG, Fung KP, Tse GM, Leung PC, Lau CB: Comparative studies of various ganoderma species and their different parts with regard to their antitumor and immunomodulating activities in vitro. J Altern Complement Med 2006, I 2(8):777-789.

4. Xie JT, Wang CZ, Wicks S, Yin JJ, Kong J, Li J, Li YC, Yuan CS: Ganoderma lucidum extract inhibits proliferation of SW 480 human colorectal cancer cells. Exp Oncol 2006, 28(I):25-29.

5. Lu QY, Jin YS, Zhang Q, Zhang Z, Heber D, Go VL, Li FP, Rao JY: Ganoderma lucidum extracts inhibit growth and induce actin polymerization in bladder cancer cells in vitro. Cancer Lett 2004, 2 I 6( I):9-20.

6. Jiang J, Slivova V, Valachovicova T, Harvey K, Sliva D: Ganoderma lucidum inhibits proliferation and induces apoptosis in human prostate cancer cells PC-3. Int J Oncol 2004, 24(5): $1093-1099$

7. Stanley G, Harvey K, Slivova V, Jiang J, Sliva D: Ganoderma lucidum suppresses angiogenesis through the inhibition of secretion of VEGF and TGF-betal from prostate cancer cells. Biochem Biophys Res Commun 2005, 330(I):46-52.

8. Wang YY, Khoo KH, Chen ST, Lin CC, Wong CH, Lin $\mathrm{CH}$ : Studies on the immuno-modulating and antitumor activities of Ganoderma lucidum (Reishi) polysaccharides: functional and proteomic analyses of a fucose-containing glycoprotein fraction responsible for the activities. Bioorg Med Chem 2002, I0(4): 1057-1062.

9. Lin KI, Kao YY, Kuo HK, Yang WB, Chou A, Lin HH, Yu AL, Wong $\mathrm{CH}$ : Reishi polysaccharides induce immunoglobulin production through the TLR4/TLR2-mediated induction of transcription factor Blimp- I. I Biol Chem 2006, 28 I (34):24 I I I-24 I 23.

10. Hsu HY, Hua KF, Lin CC, Lin CH, Hsu J, Wong CH: Extract of Reishi polysaccharides induces cytokine expression via TLR4modulated protein kinase signaling pathways. J Immunol 2004, I 73( I 0):5989-5999.

II. Chen HS, Tsai YF, Lin S, Lin CC, Khoo KH, Lin CH, Wong CH: Studies on the immuno-modulating and anti-tumor activities of Ganoderma lucidum (Reishi) polysaccharides. Bioorg Med Chem 2004, I 2(2I):5595-560I.

12. Ricciardi-Castagnoli P, Granucci F: Opinion: Interpretation of the complexity of innate immune responses by functional genomics. Nat Rev Immunol 2002, 2(I I):88I-889.

13. Skelton L, Cooper M, Murphy M, Platt A: Human immature monocyte-derived dendritic cells express the $\mathbf{G}$ protein-coupled receptor GPRIO5 (KIAA000I, P2YI4) and increase intracellular calcium in response to its agonist, uridine diphosphoglucose. J Immunol 2003, I 7 I (4): I94I-I949.

14. Malcolm KC, Arndt PG, Manos EJ, Jones DA, Worthen GS: Microarray analysis of lipopolysaccharide-treated human neutrophils. Am J Physiol Lung Cell Mol Physiol 2003, 284(4):L663-670.

15. Bild AH, Yao G, Chang JT, Wang Q, Potti A, Chasse D, Joshi MB, Harpole D, Lancaster JM, Berchuck A, et al.: Oncogenic pathway signatures in human cancers as a guide to targeted therapies. Nature 2006, 439(7074):353-357.

16. Moreno CS, Evans CO, Zhan X, Okor M, Desiderio DM, Oyesiku NM: Novel molecular signaling and classification of human clinically nonfunctional pituitary adenomas identified by gene expression profiling and proteomic analyses. Cancer Res 2005, 65(22): $10214-10222$.

17. Strausberg RL: Tumor microenvironments, the immune system and cancer survival. Genome Biol 2005, 6(3):2II.
18. Tonin PN, Hudson TJ, Rodier F, Bossolasco M, Lee PD, Novak J, Manderson EN, Provencher D, Mes-Masson AM: Microarray analysis of gene expression mirrors the biology of an ovarian cancer model. Oncogene 200I, 20(45):66I7-6626.

19. Juan HF, Lin JY, Chang WH, Wu CY, Pan TL, Tseng MJ, Khoo KH, Chen ST: Biomic study of human myeloid leukemia cells differentiation to macrophages using DNA array, proteomic, and bioinformatic analytical methods. Electrophoresis 2002, 23( I 5):2490-2504.

20. Eisenberg D, Marcotte EM, Xenarios I, Yeates TO: Protein function in the post-genomic era. Nature 2000, 405(6788):823-826.

21. von Mering C, Krause R, Snel B, Cornell M, Oliver SG, Fields S, Bork $P$ : Comparative assessment of large-scale data sets of protein-protein interactions. Nature 2002, 4l 7(6887):399-403.

22. Enright AJ, Iliopoulos I, Kyrpides NC, Ouzounis CA: Protein interaction maps for complete genomes based on gene fusion events. Nature 1999, 402(6757):86-90.

23. Marcotte EM, Pellegrini M, Ng HL, Rice DW, Yeates TO, Eisenberg $D$ : Detecting protein function and protein-protein interactions from genome sequences. Science 1999 , 285(5428):75I-753

24. Overbeek R, Fonstein M, D'Souza M, Pusch GD, Maltsev N: The use of gene clusters to infer functional coupling. Proc Natl Acad $\mathrm{Scl}$ USA 1999, 96(6):2896-290।

25. Dandekar T, Snel B, Huynen M, Bork P: Conservation of gene order: a fingerprint of proteins that physically interact. Trends Biochem Sci 1998, 23(9):324-328.

26. Pellegrini M, Marcotte EM, Thompson MJ, Eisenberg D, Yeates TO: Assigning protein functions by comparative genome analysis: protein phylogenetic profiles. Proc Natl Acad Sci USA 1999, 96(8):4285-4288.

27. Huynen MA, Bork P: Measuring genome evolution. Proc Nat Acad Sci USA 1998, 95( I I):5849-5856.

28. Sydor JR, Scalf M, Sideris S, Mao GD, Pandey Y, Tan M, Mariano M, Moran MF, Nock S, Wagner P: Chip-based analysis of proteinprotein interactions by fluorescence detection and on-chip immunoprecipitation combined with microLC-MS/MS analysis. Anal Chem 2003, 75(22):6163-6170.

29. LeBlanc HN, Ashkenazi A: Apo2L/TRAIL and its death and decoy receptors. Cell Death Differ 2003, I O(I):66-75.

30. Meurette O, Fontaine A, Rebillard A, Le Moigne G, Lamy T, LagadicGossmann D, Dimanche-Boitrel MT: Cytotoxicity of TRAIL/anticancer drug combinations in human normal cells. Ann $N Y$ Acad Sci 2006, 1090:209-216.

31. Ashkenazi A, Dixit VM: Death receptors: signaling and modulation. Science I998, 28 I(538 I): I 305-I 308.

32. Lim JH, Cho JY, Park YB, Park JW, Kwon TK: ESE-3 transcription factor is involved in the expression of death receptor (DR)-5 through putative Ets sites. Biochem Biophys Res Commun 2006, 350(3):736-74l.

33. Ashkenazi A, Dixit VM: Apoptosis control by death and decoy receptors. Curr Opin Cell Biol 1999, I I (2):255-260.

34. Gruss HJ, Boiani N, Williams DE, Armitage RJ, Smith CA, Goodwin RG: Pleiotropic effects of the CD30 ligand on CD30-expressing cells and lymphoma cell lines. Blood I994, 83(8):2045-2056.

35. Smith CA, Farrah T, Goodwin RG: The TNF receptor superfamily of cellular and viral proteins: activation, costimulation, and death. Cell 1994, 76(6):959-962

36. Sliva D: Cellular and physiological effects of Ganoderma lucidum (Reishi). Mini Rev Med Chem 2004, 4(8):873-879.

37. Bouralexis S, Findlay DM, Evdokiou A: Death to the bad guys: targeting cancer via Apo2L/TRAIL. Apoptosis 2005, I 0(I):35-5I.

38. Tang W, Liu JW, Zhao WM, Wei DZ, Zhong JJ: Ganoderic acid T from Ganoderma lucidum mycelia induces mitochondria mediated apoptosis in lung cancer cells. Life Sci 2006, 80(3):205-2II.

39. Kim KC, Kim JS, Son JK, Kim IG: Enhanced induction of mitochondrial damage and apoptosis in human leukemia HL-60 cells by the Ganoderma lucidum and Duchesnea chrysantha extracts. Cancer Lett 2007, 246(I-2):2I0-2I7.

40. Muller CI, Kumagai T, O'Kelly J, Seeram NP, Heber D, Koeffler HP: Ganoderma lucidum causes apoptosis in leukemia, lymphoma and multiple myeloma cells. Leuk Res 2006 , 30(7):84I-848. 
4I. Gu YH, Belury MA: Selective induction of apoptosis in murine skin carcinoma cells $(\mathrm{CH} 72)$ by an ethanol extract of Lentinula edodes. Cancer Lett 2005, 220(I):2I-28.

42. Hong KJ, Dunn DM, Shen CL, Pence BC: Effects of Ganoderma lucidum on apoptotic and anti-inflammatory function in HT29 human colonic carcinoma cells. Phytother Res 2004 I 8(9):768-770.

43. Hu H, Ahn NS, Yang X, Lee YS, Kang KS: Ganoderma lucidum extract induces cell cycle arrest and apoptosis in MCF-7 human breast cancer cell. Int J Cancer 2002, I 02(3):250-253.

44. BioCarta Pathway Database [http://www.biocarta.com/]

45. KEGG (Kyoto Encyclopedia of Genes and Genomes) Pathway Database [http://www.genome.jp/kegg/pathway.html]

46. NCl's Cancer Genome Anatomy Project (CGAP)Pathways [http://cgap.nci.nih.gov/Pathways]

47. Chung HJ, Kim M, Park CH, Kim J, Kim JH: ArrayXPath: mapping and visualizing microarray gene-expression data with integrated biological pathway resources using Scalable Vector Graphics. Nucleic Acids Res 2004:W460-464.

48. Gao Y, Camacho LH, Mehta K: Retinoic acid-induced CD38 antigen promotes leukemia cells attachment and interferongamma/interleukin-I beta-dependent apoptosis of endothelial cells: implications in the etiology of retinoic acid syndrome. Leuk Res 2007, 3 I (4):455-463.

49. Sato K, Taniguchi T, Suzuki M, Shinohara F, Takada H, Rikiishi H: Dual role of NF-kappaB in apoptosis of THP-I cells during treatment with etoposide and lipopolysaccharide. Leuk Res 2004, 28(I):63-69.

50. Zhao X, Mohaupt M, Jiang J, Liu S, Li B, Qin Z: Tumor necrosis factor receptor 2-mediated tumor suppression is nitric oxide dependent and involves angiostasis. Cancer Res 2007 67(9):4443-4450.

51. Kumar A, Eby MT, Sinha S, Jasmin A, Chaudhary PM: The ectodermal dysplasia receptor activates the nuclear factor-kappaB, JNK, and cell death pathways and binds to ectodysplasin A. J Biol Chem 200I, 276(4):2668-2677.

52. Bredel M, Bredel C, Juric D, Duran GE, Yu RX, Harsh GR, Vogel H, Recht LD, Scheck AC, Sikic BI: Tumor necrosis factor-alphainduced protein 3 as a putative regulator of nuclear factorkappaB-mediated resistance to O6-alkylating agents in human glioblastomas. J Clin Oncol 2006, 24(2):274-287.

53. Takeda K, Kaisho T, Akira S: Toll-like receptors. Annu Rev Immunol 2003, $21: 335-376$

54. Storey JD, Xiao W, Leek JT, Tompkins RG, Davis RW: Significance analysis of time course microarray experiments. Proc Natl Acad Sci USA 2005, 102(36): 12837-1 2842.

55. Ou CH, Chang CC, Hsia HC, Wang FS, Juan HF, Huang HC: BSIP a web server for systems-biology structure identification program development (EITC-06). The Sixth Annual Emerging Information Technology Conference: Aug 10-12 2006; Dallas, USA 2006.

56. Tsai KY, Wang FS: Evolutionary optimization with data collocation for reverse engineering of biological networks. Bioinformatics (Oxford, England) 2005, 2 I(7): I I80-1 I 88.

57. Wajant $\mathrm{H}$, Pfizenmaier $\mathrm{K}$, Scheurich $\mathrm{P}$ : Tumor necrosis factor signaling. Cell Death Differ 2003, I 0(I):45-65.

58. Sheikh MS, Huang Y: Death receptor activation complexes: it takes two to activate TNF receptor I. Cell Cycle 2003, 2(6):550-552.

59. MacEwan $D$ J: TNF receptor subtype signalling: differences and cellular consequences. Cell Signal 2002, I 4(6):477-492.

60. Ravi R, Bedi GC, Engstrom LW, Zeng Q, Mookerjee B, Gelinas C Fuchs EJ, Bedi A: Regulation of death receptor expression and TRAIL/Apo2L-induced apoptosis by NF-kappaB. Nat Cell Biol 200I, 3(4):409-4I6

6I. Gupta S: A decision between life and death during TNF-alphainduced signaling. J Clin Immunol 2002, 22(4): I85- I94.

62. de Hoon MJ, Imoto S, Nolan J, Miyano S: Open source clustering software. Bioinformatics (Oxford, England) 2004, 20(9): I 453-I 454

63. Juan HF, Huang HC: Bioinformatics: microarray data clustering and functional classification. In Microarrays: Applications and Data Analysis Volume 2. 2nd edition. Edited by: Jang B. Rampal. . New Jersey: Humana Press; 2007:405-16.

64. Ashburner M, Ball CA, Blake JA, Botstein D, Butler H, Cherry JM, Davis AP, Dolinski K, Dwight SS, Eppig JT, et al.: Gene ontology: tool for the unification of biology. The Gene Ontology Consortium. Nat Genet 2000, 25(I):25-29.
65. Beacon Designer Software [http://www.premierbiosoft.com/]

66. EDGE Software Package [http://www.biostat.washington.edu/ software/jstorey/edge/]
Publish with Biomed Central and every scientist can read your work free of charge

"BioMed Central will be the most significant development for disseminating the results of biomedical research in our lifetime. "

Sir Paul Nurse, Cancer Research UK

Your research papers will be:

- available free of charge to the entire biomedical community

- peer reviewed and published immediately upon acceptance

- cited in PubMed and archived on PubMed Central

- yours - you keep the copyright

Submit your manuscript here:

http://www.biomedcentral.com/info/publishing_adv.asp
BiolMedcentral 